\title{
Bringing corporate governance into internalization theory: State ownership and foreign entry strategies
}

\author{
Birgitte Grøgaard ${ }^{1}$, \\ Asmund Rygh ${ }^{2}$ and \\ Gabriel R. G. Benito ${ }^{1}$ \\ ${ }^{7}$ BI Norwegian Business School, Nydalsveien 37, \\ 0484 Oslo, Norway; ${ }^{2}$ Alliance Manchester \\ Business School, The University of Manchester, \\ Manchester M15 6PB, UK \\ Correspondence: \\ B Grøgaard, BI Norwegian Business School, \\ Nydalsveien 37, 0484 Oslo, Norway. \\ Tel: +47 464105 35; \\ e-mail: birgitte.grogaard@bi.no
}

\begin{abstract}
We use internalization theory to analyze the establishment and entry mode decisions of state-owned (SOE) and privately owned (POE) enterprises. We enrich internalization theory by building on insights from economic theory of corporate governance and taking into account particular characteristics of SOEs such as non-economic motivations, long-term orientation, and different risk preferences. We examine foreign entries over a 10-year period in the Canadian oil and gas industry. This single-country and single-industry context features foreign SOEs and POEs from a wide range of home countries, allowing a focused study of the combined influence of state ownership and home-country factors. Compared to POEs, SOEs tend to prefer acquiring stand-alone assets rather than firms, and to take lower ownership shares. We also find that differences between SOEs and POEs diminish when home countries are characterized by high government quality and market orientation and identify differences between types of SOEs, with partially owned SOEs exhibiting behaviors more similar to POEs than fully owned SOEs. We demonstrate how our enrichment of internalization theory strengthens its predictive and explanatory capacity. Our results also show that SOEs from strong and market-oriented institutional environments are similar to POEs and can be studied using the traditional internalization theory.
\end{abstract}

Journal of International Business Studies (2019) 50, I310-1337.

https://doi.org/10.1057/s41267-019-00237-5

Keywords: state ownership; internalization theory; corporate governance; foreign market entry; multinational enterprise; oil and gas industry

\section{INTRODUCTION}

Internalization theory is one of the most influential theories within international business (IB), and is often considered the general theory of the multinational enterprise (MNE) (Narula \& Verbeke, 2015; Rugman 1981). It is widely used to explain why and how firms expand abroad. However, it is largely developed through research on privately owned enterprises (POEs) in manufacturing industries, where rivalry amongst profit-seeking actors supposedly promotes economically efficient operation modes ${ }^{1}$ (Buckley \& Casson, 1976), raising questions - e.g., by Rugman (1983) regarding its applicability to other market actors such as state-
Received: 31 May 2017

Revised: 13 November 2018

Accepted: 17 January 2019

Online publication date: 15 May 2019 
owned enterprises (SOEs). Over the past decade, the global economy has seen a surge in the international activities of SOEs (George, Schillebeeckx \& Liak, 2015). According to Fortune's Global 500 rankings, three of the top ten companies were stateowned in 2017, compared to one SOE ranked 17th among the top 20 only a decade earlier (Fortune 2007, 2017). This changing global competitive landscape has generated substantial policy interest as well as research interest among IB scholars (Buckley, Doh, \& Benischke, 2017; Cuervo-Cazurra, Inkpen, Musacchio, \& Ramaswamy, 2014; Hu, Cui \& Aulakh, 2019).

Internalization theory assumes that firms will choose economically efficient ways of entering foreign markets in the sense of minimizing transaction costs (Grøgaard \& Verbeke, 2012; Narula \& Verbeke, 2015). There are particularly three important characteristics often associated with SOEs (Cuervo-Cazurra et al., 2014; Shapiro \& Globerman, 2012) which could indicate SOEs fit less well with internalization theory. First, SOEs may have other motivations than private firms. Unlike private firms that are presumably profit-motivated, SOEs may pursue social, distributional, or even ideological goals that are often long-term oriented. Second, SOEs may have different risk preferences than POEs. In particular, state ownership is often assumed to imply a higher tolerance of risk (Arrow \& Lind, 1970). Third, and related to the first two characteristics, SOEs may suffer from particular corporate governance failures and lack of proper management incentives, which potentially hinder development of firm-specific advantages (FSAs).

Such differences between SOEs and POEs led internalization scholars like Rugman (1983) to question if internalization theory applies to SOEs. ${ }^{2}$ In this paper, we argue that internalization theory can be extended to also apply to SOEs. Such an extension, however, requires more attention to the variety of goals and risk preferences of a firm's owners and managers. While such aspects have so far been largely overlooked in internalization theory, which has explicitly or implicitly tended to assume profit maximization and risk neutrality (see Buckley \& Strange, 2011; Strange, 2018), they play a key role in related economic theories of corporate governance, including perspectives that Hoenen and Kostova (2015) refer to as 'the broader agency perspective'. These include theories such as agency theory and incomplete contracts theory that have previously been used to understand the motivations for and implications of state ownership
(Boycko, Shleifer, \& Vishny, 1996; Martimort, 2006; Megginson \& Netter, 2001; Rygh, 2018).

In this paper, we advance internalization theory by leveraging state-owned MNEs as a context for widening the scope of firms' objectives, time horizons, and risk preferences. Such characteristics may lead to distinct benefits and costs of internalization that are different from those from the purely profitmaximizing and risk-neutral firm traditionally considered in internalization theory, and hence systematically lead to different internalization decisions. Moreover, we advance internalization theory by recognizing and explicitly dealing with the implications of goal conflicts between owners and managers. Such goal conflicts have been extensively explored in the state-ownership literature and are often assumed to lead to particular governance issues in SOEs (Martimort, 2006). Moreover, this literature suggests an indirect effect of state ownership on internalization decisions to the extent that corporate governance issues could hinder SOEs' economic efficiency and their development of FSAs (e.g., Rugman \& Li, 2007; Shleifer \& Vishny, 1997).

Our analysis also helps us understand why all SOEs are not the same: The goals, time horizons, and risk preferences of SOEs are affected by contextual factors such as home-country characteristics (Aguilera \& Grøgaard, 2019). Recent studies have highlighted how SOEs differ considerably in terms of how they are governed, e.g., with regard to degree of state ownership and state influence on strategy and management (e.g., Cavaliere \& Scabrosetti, 2008; Estrin, Meyer, Nielsen, \& Nielsen, 2016; Musacchio \& Lazzarini, 2014; Musacchio, Lazzarini, \& Aguilera, 2015). Many SOEs initially operated as large domestic monopolies, managed by governments with explicit social and political motivations. By the 1980s, several developed and developing countries initiated full or partial privatization of a large number of SOEs (Musacchio \& Lazzarini, 2014). As a result, today's SOEs are highly diverse in terms of their ownership structures and governance. It is now widely recognized that a dichotomous approach to state ownership (i.e., yes/ no) neglects the multitude of variations in terms of state involvement. Governments vary in their ownership levels from minority positions to majority or full ownership. It is also increasingly common to find partial state ownership in listed firms (Estrin et al., 2016), even where the state has majority ownership such as in Equinor (formerly Statoil of Norway) or CNOOC (China). Many SOEs 
have recently gone through changes aiming to develop more professionalized management practices, decision-making, and governance (CuervoCazurra et al., 2014). Thus, features of the homecountry institutional environment such as government quality and market orientation have implications for non-economic objectives, risk preferences, and SOE corporate governance.

We apply our enriched internalization theory to decisions about how to enter foreign markets, a key application for internalization theory (Brouthers \& Hennart, 2007; Datta, Hermann, \& Rasheed, 2002; Grøgaard \& Verbeke, 2012; Morschett, SchrammKlein, \& Swoboda, 2010; Slangen \& Hennart, 2007; Tihanyi, Griffith, \& Russel, 2005; Welch, Benito, \& Petersen, 2018), analyzing SOE and POE establishment modes (acquisition of firms versus standalone assets) and entry modes (wholly owned versus jointly owned). Our empirical context is transactions of stand-alone assets and firms in the Canadian oil and gas industry over the period 2005-2016. Our research design and empirical setting is uniquely suited for testing our arguments on how state ownership and home contexts affect internalization decisions. By studying the behavior of SOEs and POEs from many different homecountry contexts entering a single host country and industry with strong competitive pressures, we avoid heterogeneity in terms of industries and host-country institutional contexts.

Our results broadly support our hypotheses on the effects of state ownership and on how these effects depend on the home-country context. We find that SOEs on average have a preference for acquiring stand-alone assets rather than firms and for taking lower ownership levels. However, an equally striking result is that there is generally a clear convergence in the strategies of SOEs and POEs from home countries with high government quality and market orientation, consistent with our arguments of how the home context affects their choices.

We strengthen the explanatory and predictive capacity of internalization theory by drawing on economic corporate governance perspectives that provide a fuller understanding of the goals and risk preferences of actors. In this way, we demonstrate that internalization theory has a wider scope of application than may so far have been assumed, and suggest how it can be extended to study phenomena previously assumed to be outside the scope of the theory, such as SOEs (Rugman, 1983). Our enriched internalization theory perspective also strengthens our understanding of the role of ownership in firms' decisions about how to enter foreign markets (cf. Strange, 2018). In particular, we contribute to the growing state-owned MNE literature by showing the relevance of an extended version of internalization theory to explain their foreign entry strategies. Our results demonstrate that the effect of state ownership depends both on the SOE's home-country context and on the type of state ownership. This suggests caution is needed when generalizing previous findings based almost exclusively on Chinese SOEs' entry strategies to SOEs in general.

The next section briefly reviews internalization theory, the literature on SOE internationalization, and the corporate governance-based literature on SOEs. We then use our broadened internalization theory to derive hypotheses on decisions about how SOE enter foreign markets. Next follow descriptions of our empirical context, methods and results, and a discussion section exploring the contributions and limitations of our study.

\section{INTERNALIZATION THEORY MEETS CORPORATE GOVERNANCE: THE INTERNATIONAL ACTIVITIES OF STATE- OWNED ENTERPRISES}

According to Buckley, an axiom of internalization theory is that "firms grow by internalizing markets up to the point where the benefits of further internalization are outweighed by the costs" (1988: 182). From its early focus on foreign direct investment (FDI) versus other operating modes (Buckley \& Casson, 1976; Hennart, 1982; Rugman, 1981), internalization theory has developed into one of the dominant and most comprehensive theoretical perspectives within the IB literature to understand key decisions related to cross-border activities (Grøgaard \& Verbeke, 2012; Kano, 2018; see also Asmussen, Benito, \& Petersen, 2009). Championed by Alan Rugman, "new" internalization theory enables us to understand and predict how MNEs set their firm boundaries to develop and utilize their FSAs when interacting with their external environments (Narula \& Verbeke, 2015; Rugman \& Verbeke, 2008). As Narula \& Verbeke state, "internalization theory is meant to be a general theory on how to organize IB transactions, with considerable power to explain and predict regularities in IB governance choices. Such regularities involve, inter alia, the choice of operating mode..." (2015: 614). 
Internalization theory proposes that FSAs influence firms' foreign entry strategies. FSAs can either be transferable (non-location-bound) such as technological knowledge, or specific to a local context (location-bound) such as local market knowledge and access to local networks (Rugman \& Verbeke, 2001). MNEs typically lack some key locationbound FSAs when entering a foreign market, reflecting a "liability of outsidership" (Johanson \& Vahlne, 2009). Necessary complementary locationbound assets can be accessed through multiple types of markets (i.e., markets for asset services, markets for assets, and markets for firms). Seeking to exploit and develop FSAs successfully, internalization theory assumes that market actors are profit-seeking rational decision-makers, well illustrated by the following quotes from Buckley \& Casson (1976): "The theory developed below... depends on the assumption of profit-maximisation" (p. 32); and "Our theory is based on ... (1) Firms maximize profit in a world of imperfect markets..." (p. 33). This involves market entry decisions that minimize challenges with information asymmetry (bounded rationality) and safeguard against contractual failures due to opportunism or benevolent preference reversals (bounded reliability) (Narula \& Verbeke, 2015).

Another key concept in internalization theory (following Rugman, 1981) is country-specific advantages (CSAs). CSAs cover a wide range of external factors that affect firm performance such as labor, technology levels, natural resources or the institutional environment. For MNEs, both homecountry and host-country CSAs are relevant, and FSAs and CSAs are interlinked as MNEs tap into CSAs to utilize or develop their FSAs. CSAs have attracted renewed attention not least in the context of emerging market MNEs (Gugler, 2017; Hennart, 2012). In line with internalization theory, we expect that firms' abilities to develop FSAs are influenced by their external contexts (Narula \& Verbeke, 2015; Rugman \& Verbeke, 2003). Previous studies have also found an important effect of home-country characteristics such as the strength of institutions on different aspects of internationalization (e.g., Bhaumik, Driffield, \& Pal, 2010; Duanmu, 2014; Filatotchev, Strange, Piesse, \& Lien, 2007; Gaur, Ma, \& Ding, 2018; Shi, Sun, Yan, \& Zhu, 2017). This should apply to SOEs as well as POEs.

Despite the prevalence of internalization theory in IB literature, its application to SOEs has been limited, perhaps reflecting an assumption that it does not fit with SOEs (Rugman, 1983). Instead, the IB literature on SOEs' choice of foreign market entry and establishment modes has tended to take an institutional perspective, arguing that specific configurations of home and host-country institutional pressures may inter alia lead SOEs to take lower ownership positions (Cui \& Jiang, 2012; Meyer, Ding, Li, \& Zhang, 2014). Yet, given that SOEs are both economic and political creatures, institutional theory may not be able to provide the full picture. Foreign entry studies based on institutional theory have furthermore largely been based on the somewhat idiosyncratic case of China, while SOEs originate from a wide range of different home contexts.

While recognizing the insights provided by studies based on institutional theory, we posit that internalization theory can be extended to strengthen its capacity for explaining and predicting SOEs' strategic decisions when entering competitive foreign markets. This requires, however, a broadening of the view of possible motivations for internalization to capture governments' non-economic motivations and different time horizons and risk preferences. Moreover, more attention to the particular corporate governance mechanisms of SOEs is needed. On these issues, other economic theories of governance provide a useful complement to internalization theory in terms of their focus and key assumptions (cf. Buckley \& Strange, 2011; Okhuysen \& Bonardi, 2011). While internalization theory focuses on the boundaries of the firm in a broad sense, corporate governance theories such as agency theory have focused on issues such as diverging goals, risk preferences and incentives between actors (Eisenhardt, 1989; Buckley \& Strange, 2011; Filatotchev \& Wright, 2011) and explored particular features of the agency relationships in SOEs (e.g., Hart, Shleifer \& Vishny, 1997; Martimort, 2006; Sappington \& Stiglitz, 1987). Also, while internalization theory assumes profit maximizing decisions, economic theories of governance such as agency theory allow for owners to have non-economic motivations and for managers to have private motivations that deviate from those of the owners. Both of these assumptions are important to understand SOEs. Finally, both internalization theory and related economic theories of governance acknowledge the role of uncertainty and information asymmetry, while assuming purposeful contracting by rational market actors (Strange et al., 2009). However, while internalization theory implicitly assumes risk neutral 
decision-makers, risk preferences play an important role in economic theories of governance (Buckley \& Strange, 2011; Chiles \& McMackin, 1996; Eisenhardt, 1989; Elia, Larsen, \& Piscitello, 2019).

\section{The Corporate Governance of SOEs}

Two key economic theories of corporate governance applied to firms in general and SOEs in particular have been agency theory and incomplete contracts theory (Martimort, 2006; Megginson \& Netter, 2001). Although the corporate governance literature is diverse and continually developing (Bolton \& Dewatripont, 2005; Laffont \& Martimort, 2002), the broader agency-based corporate governance literature (Hoenen \& Kostova, 2015) traditionally focused on the implications of delegating the running of companies from owners to managers and mechanisms for ensuring that managers maximize the returns for shareholders (e.g., Jensen \& Meckling, 1976; Fama \& Jensen, 1983). For SOEs, however, the owner's objectives are not necessarily (only) profit seeking, but may also include addressing market failures, redistribution, and ideological motives (Cuervo-Cazurra et al., 2014). Moreover, the risk preferences and time horizons of state owners play key roles in economics literature on state ownership. In principle, due to its high degree of diversification, the state-owner is approximately risk neutral (Arrow \& Lind, 1970). In principle being infinitely lived, a state may also have a longer time horizon than private owners. In particular, such analyses suggest that using state ownership, rather than contracting out the provision of the public service to a private firm, may be motivated by risk aversion or financial constraints of POEs. Furthermore, state ownership may be motivated by the inability to write complete contracts with POEs (Sappington \& Stiglitz, 1987; Hart et al., 1997; Martimort, 2006). Recently, such arguments for state ownership have been applied to state-owned MNEs by Rygh (2018).

While the above arguments for state ownership assume "benevolent" politicians pursuing citizens' interests when governing SOEs, the economic theory of governance literature has also qualified this view by exploring particular corporate governance issues in SOEs. State ownership is characterized by a multi-layered delegation structure where voters (the ultimate owners of an SOE) delegate control to politicians via bureaucrats to SOE managers. In this view, politicians and/or bureaucrats may also pursue private interests. The public choice approach to politics assumes politicians motivated mainly by re-election may use SOEs to reward political supporters (Shleifer \& Vishny, 1994). Although these arguments were developed based on democratic countries with free elections, the arguments are also applicable with some modification to more autocratic settings. While the scope for using SOEs for self-interested purposes may be even greater (Clegg, Voss, \& Tardios, 2018), autocratic leaders still depend on political support. As for the bureaucrats tasked with the daily monitoring of SOEs, they have weak monetary incentives to devote effort to monitoring, as their financial stake is insignificant, while SOEs' multidimensional objectives make their governance more difficult.

Moreover, corporate governance mechanisms for disciplining managerial behavior such as stock market monitoring, the threat of takeovers, and bankruptcy (e.g., Fama \& Jensen, 1983) are weaker or deactivated in SOEs. Further, in contrast to POEs that are restricted from spending financial funds beyond what their owners are willing to raise and risk, SOEs are less financially restricted as they may draw on state funds and may perceive that the owner-state will be reluctant to let an SOE go bankrupt as this may lead to political costs. This moral hazard issue, often associated with the idea of a SOE "soft budget constraint" (Kornai, 1979), may be another factor leading to a risk willingness of SOEs (Knutsen, Rygh, \& Hveem, 2011; Vernon, 1979). These corporate governance issues in SOEs are generally perceived to result in economic inefficiencies and weaker FSAs (Shapiro \& Globerman, 2012), which may be a further indirect reason why SOEs display different internalization strategies from POEs.

\section{The Influence of Context on State Ownership}

The discussion above has suggested that SOEs' noneconomic motivations, time horizons, different risk preferences and particular corporate governance features may all lead them to pursue different strategies in general, and different internalization strategies in particular. However, SOEs originate from widely different contexts. Moreover, while corporate governance and public choice arguments for SOEs tended to be seen as universal and independent of context, more recent literature has explored the implications of aspects such as the quality of the institutions that politicians and bureaucrats are functioning within, for state ownership (e.g., Cavaliere \& Scabrosetti, 2008; Cuervo \& Villalonga, 2000; Estrin et al., 2016). 
Two aspects of the context of SOEs are of particular importance to our study. First, government quality is likely to be important by reducing the scope for politicians, bureaucrats and SOE managers to pursue their own interests at the expense of the social interest. Professional and independent government institutions will reduce the degree of (undue) political interference in SOE operations (Evans \& Rauch, 1999), and ensure strong SOE corporate governance where the state owner is treated just like any other owner (e.g., Knutsen et al., 2011). Also, the scope for politicians and bureaucrats to pursue private goals using SOEs is likely to be smaller when home government quality is higher. Finally, moral hazard issues relating to a SOE soft budget constraint (Kornai, 1979) are also likely to be mitigated since the government's credibility of SOE governance is increased, meaning that SOEs' risk appetite could be reduced. In such a context, differences between SOEs and POEs should reflect social welfare-maximizing governments rather than politicians, bureaucrats and SOE managers pursuing their private interests (cf. Cavaliere \& Scabrosetti, 2008).

Second, market orientation reflects preferences within a country regarding state intervention in the economy and hence the scope of non-economic objectives for SOEs. In market-oriented countries, the preferences of citizens and politicians themselves will circumscribe the scope for non-economic goals for SOEs. More broadly, a home-country market orientation also has SOE corporate governance implications, in terms of the scrutiny of SOEs to be efficient and market competition from private firms (Megginson \& Netter, 2001; Goldeng, Grünfeld, \& Benito, 2008). Countries with a strong market orientation also tend to have lower barriers for setting up business and encourage competition. SOEs from marketoriented contexts are thus pushed to improve their economic performance and develop strong FSAs, weakening another channel of differences in behavior between SOEs and POEs.

All else equal, a higher degree of government quality and market orientation will reduce the differences between SOEs and POEs. However, they are distinct dimensions, since government quality is required also to successfully implement noneconomic objectives, while a strong market orientation may require well-functioning institutions to produce the desired results, as suggested by many countries' privatization experiences (Cuervo \& Villalonga, 2000).

\section{Purchasing Stand-Alone Assets Versus Firms}

Internalization theory assumes that MNEs choose establishment modes to minimize transaction costs and hence improve overall economic performance. When seeking exploration and production opportunities in oil and gas, MNEs may choose either to purchase stand-alone natural resource assets or registered firms. Stand-alone assets range from undeveloped land requiring extensive exploratory activity, which is characterized by higher risks, the potential need for significant investments over time, combined with highly uncertain payoffs (Bass \& Chakrabarty, 2014), to more or less complete physical assets (developed land with equipment) that can be further combined and/or developed. While the latter is not necessarily exploratory activity, there are still significant risks involved when assets are purchased without attachment to a registered firm, supporting activities, or employees needed to create value from the assets. If exploratory stand-alone assets are successfully developed, they can lead to exponential growth, but are capital intensive before any economic benefits can be realized and require expertise to explore and develop. Registered firms typically have ongoing operations based on a portfolio of multiple assets. Although exploratory activities may be part of the overall portfolio when a firm is acquired, the direct impact of risks related to these assets is balanced and diversified by more predictable values of other assets that are part of the firm's portfolio (Bass \& Chakrabarty, 2014).

SOEs typically have a longer-term orientation, and SOEs in natural resource industries frequently pursue what Bass \& Chakrabarty (2014) have termed resource security. Although firms may have both short- and long-term strategic intents of securing natural resources, we expect SOEs to differ from POEs in their focus and ability to pursue longterm resource security objectives, favoring standalone assets. Hence, state ownership points to a preference for assets that represent resources for the longer run and may have higher potential for growth and high returns, but also represent longterm capital intensive projects ${ }^{3}$ with significantly higher risk. Risk tolerance favors the development of stand-alone assets with larger long-term upside potential. This preference for stand-alone assets is amplified by softer budget constraints (Kornai, 1979; Boycko et al. 1996; Rygh, 2018) that allow SOEs to take on the risks associated with developing stand-alone assets without requiring immediate 
economic returns. The risk tolerance effect could be further strengthened to the extent that moral hazard leads SOE managers to take excessive risks in the expectation that they would be bailed out in the case of failed projects. The channels relating to long-term orientation, resource security goals, and risk tolerance would, all else equal, make SOEs more likely to acquire stand-alone assets for future development. In contexts with weaker control of politicians, there might be a stronger element of private motives of politicians ("empire building"), with politicians preferring spectacular actions that attract attention and boost national pride. "Hoarding" stand-alone assets abroad might be perceived by their constituencies at home as addressing important resource security issues.

In traditional internalization theory, corporate governance (ownership of the MNE) would not be part of the model, the (typically implicit) assumption being that firms are profit-maximizing POEs, so the theory would emphasize what factors would lead firms to prefer an establishment mode over another. Importantly, internalization theory predicts that the acquisition of firms may be particularly valuable when the MNE needs to access certain FSAs and CSAs in a host market. The purchase of stand-alone assets requires strong FSAs to orchestrate resources and activities successfully within or across assets. Hence, if the MNE brings strong FSAs to the host market, it is more capable of purchasing stand-alone assets to exploit these FSAs efficiently (Hennart, 2009).

The internalization theory perspective on FSA development would suggest that SOEs are less able than POEs to acquire and build up relevant knowledge and managerial competences (e.g., Lawson, 1994; Rugman \& Li, 2007). If SOE managers or board members are appointed based on political factors rather than business or technological competence, this could be one reason for weaker FSAs in this area. SOEs are generally also characterized by less high-powered incentives, which could reduce the incentives of employees to gain certain types of business knowledge. More generally, some privatization studies have argued that private ownership can improve performance through certain changes in organizational culture and structure (see Cuervo \& Villalonga, 2000), which could also influence FSAs. This could in turn imply that SOEs bring weaker FSAs to exploit stand-alone assets in foreign markets and therefore tend to prefer acquisitions of firms in order to access necessary (tacit) technological, managerial, or market-specific knowledge (Slangen \& Hennart, 2007) held by POEs.

The balance between these counteracting effects of state ownership is likely to depend on the homecountry context of the SOE. Higher government quality implies improved SOE governance, reduced undue political influence and that SOEs are allowed to focus on their core goals. Even if resource security (Bass \& Chakrabarty, 2014) could be an accepted goal pursued by SOEs independent of home-country government quality, better government quality could mitigate excessive "hoarding" purported to address resource security. Moreover, higher government quality would likely reduce excessive risk-taking following from moral hazard issues; beyond any higher tolerance for risk governments would like to promote. We acknowledge the potential contradicting effect in that stronger corporate governance would reduce FSA deficiencies, but this effect may be weakened since stronger corporate governance would also reduce the incidence of less appropriate internalization decisions; SOEs, deviating from what would be optimal for a POE, could all else equal purchase firms to a lesser extent than a POE facing comparable FSA shortages. This implies that SOEs might have a lower propensity to purchase firms than an assessment of their FSAs would suggest from an efficiency-seeking perspective, a problem that would in turn be mitigated as government quality increases. Hence, our first hypothesis is as follows:

Hypothesis 1a: Ceteris paribus, SOEs from home-country contexts with poor government quality are less likely (in comparison to POEs) to acquire firms rather than stand-alone assets. As home countries' government institutions strengthen, the choices made by SOEs and POEs will tend to converge.

Second, the effect of state ownership is also likely to be smaller if the SOE originates from a marketoriented economy that enables private ownership and market competition (Goldeng et al., 2008). Home governments may differ in what goals they have for their SOEs. While some SOEs internationalize with a mandate to secure long-term access to natural resources for their home country (Bass \& Chakrabarty, 2014), other SOEs pursue more business-oriented motives. In a market-oriented economy, the politically determined scope of the goals pursued by SOEs is likely to be more circumscribed, 
and there may therefore be less willingness to use SOEs to achieve resource security (which, we have argued in this context implies a preference for stand-alone assets). Thus we hypothesize:

Hypothesis 1b: Ceteris paribus, SOEs from home-country contexts with weak market orientation are less likely (in comparison to POEs) to acquire firms rather than stand-alone assets. As home countries' market orientation strengthens, the choices made by SOEs and POEs will tend to converge.

\section{Degree of Ownership}

Whether firms enter markets by acquiring standalone assets or firms, they must also choose the appropriate level of ownership (Brouthers \& Hennart, 2007; Welch et al., 2018). Again, our enriched internalization theory perspective suggests an indirect effect of state ownership via FSAs as well as effects from non-economic objectives and risk tolerance; in this case, the arguments all point in the direction of lower ownership levels taken by SOEs. A firm's success when entering and operating in foreign markets is typically contingent on its ability to access and recombine its own FSAs with necessary complementary assets and capabilities in the host market (Hennart, 2009). This can be achieved either through market contracts or partnerships. According to internalization theory, MNEs prefer strategic partnerships such as joint ventures if their own FSAs and the local complementary assets and capabilities are difficult to transact through contractual arrangements. In contrast, MNEs prefer high ownership and control when their own FSAs are difficult to transact, but necessary complementary assets and capabilities are easy to access through contractual arrangements in the host market (Grøgaard \& Verbeke, 2012). Difficulties of transacting FSAs in host markets have been attributed to both asset specificity and information asymmetry (Brouthers \& Hennart, 2007; Chi \& Roehl, 1997).

If SOEs indeed suffer from weaker managerial and technical FSAs, they will rely more on local complementary assets and capabilities, and tend to choose lower levels of ownership. SOEs may also have weaker FSAs than POEs in transacting for local complementary assets and capabilities such as hiring qualified local people with specific location-bound competencies, suggesting they will to a greater extent seek joint ventures with firms possessing such capabilities. The ability to bundle complementary capabilities is particularly important in complex competitive environments such as the oil and gas industry (Garcia, Lessard, \& Singh, 2014). Moreover, deficient corporate governance could imply internalization decisions that do not minimize transaction costs.

However, non-economic objectives could also imply that SOEs have different benefits of ownership than POEs, and achieving such objectives may require different levels ownership than pursuing purely economic objectives. As suggested by Bass and Chakrabarty (2014), in the case of oil and gas resources, the main objective for SOEs is likely to be ensuring long-term resource access. If so, SOEs may be content with a level of ownership that ensures this aim, which may be lower than an ownership level chosen by a POE for reasons of value appropriation.

Moreover, different risk preferences could also influence the choice of ownership level. If SOEs have greater risk tolerance, they may see a lesser need than POEs to protect their FSAs through internalization and would choose lower ownership levels. This is consistent with the argument that relatively risk-seeking agents avoid integration until higher levels of asset specificity (Chiles \& McMackin, 1996). Pan, Teng, Supapol, Lu, Huang, and Wang (2014) argue that higher risk tolerances and additional support from home-governments reduce Chinese SOEs' concern about potential transaction costs, finding that state ownership negatively moderates the relationship between host-country risk and ownership of foreign subsidiaries. Li and Xie (2013) find Chinese SOEs are less affected by variables related to information asymmetry in cross-border acquisitions such as target technology level, relatedness of industry, and cultural distance. They ascribe this to SOEs being less concerned with profit maximization and less subject to market selection mechanisms forcing firms to choose efficient operating modes, but their results are also consistent with the notion of noneconomic motives for internalization and higher SOE risk tolerance.

Following Estrin et al. (2016), self-interested politicians may also prefer lower SOE resource commitment abroad if rent-seeking is easier for domestically based SOE assets. This might, all else equal, lead SOEs to take lower ownership positions in FDIs. Lower ownership positions among Chinese SOEs have been attributed the home-country's preference for lower resource commitment modes (Lee, Hemmert, \& Kim, 2014). 
While these arguments suggest a lower ownership level taken by SOEs on average, again we expect the effect to be moderated by the homecountry context. Higher home government quality will make the channel related to weaker FSAs of SOEs less relevant, by improving SOE governance. There would then be less need for SOEs to team up with private firms in order to compensate for their own (comparative) weaknesses, beyond the general expectation that firms' success in foreign markets also relies on their ability to access valuable complementary resources. In addition, with better corporate governance we would expect that SOEs become more concerned about protecting a given set of FSAs through internalization, and hence also for this reason become more similar to POEs as home government quality improves. Finally, better government quality reduces the scope for politicians to restrict resource commitment abroad in order to pursue private motives by (Estrin et al., 2016), while managerial moral hazard issues leading to excessive risk taking will also be alleviated. Thus, we hypothesize:

Hypothesis 2a: Ceteris paribus, SOEs from home-country contexts with poor government quality are more likely (in comparison to POEs) to choose a lower level of ownership in the investment object. As home countries' government institutions strengthen, the choices made by SOEs and POEs will tend to converge.

A stronger home-country market orientation will have many of the same effects on FSAs and governance by promoting competition and increasing the pressure for good governance of SOEs. In addition, a stronger market orientation is likely to imply a shift from non-economic motives towards economic ones, making non-economic influences on ownership levels less important. This will lead to a choice of ownership level more similar to the benchmark represented by a comparable POE motivated by value appropriation. Thus, we hypothesize:

Hypothesis 2b: Ceteris paribus, SOEs from home-country contexts with weak market orientation are more likely (in comparison to POEs) to choose a lower level of ownership in the investment object. As home countries' market orientation strengthens, the choices made by SOEs and POEs will tend to converge.



Figure 1 Conceptual model.

Figure 1 summarizes our conceptual model and the four hypotheses.

\section{EMPIRICAL CONTEXT AND DATA}

Our data consist of transactions of assets and firms in the Canadian oil and gas industry between 2005 and $2016{ }^{4}$ This empirical context is highly suitable for our study. First, while SOE internationalization has been observed across various industries, the oil and gas industry remains very important (Cannizzaro \& Weiner, 2018). The oil and gas industry ranks among the top five global industries with SOE shares (UNCTAD, 2017). There is a growing trend of previously domestic SOEs seeking access to natural resources in foreign markets (OECD, 2014) and Canada, with its vast natural resources, has become one of the most targeted countries for SOE investments (CERI, 2013; OECD, 2013). Canada has the world's third largest oil and gas reserves, and inward FDI has averaged tens of billions of dollars per year since 2007 (CERI, 2013). Moreover, the fact that natural resource-seeking MNEs' choices of location are limited by the availability of resources mitigates concerns about selection bias related to host-country selection (Cannizzaro \& Weiner, 2018).

Second, while most SOE foreign entry studies have so far examined Chinese MNEs (with some exceptions such as Bass and Chakrabarty (2014) and Karolyi and Liao (2017) using multi-country samples), we are able to study foreign entry strategies of SOEs and POEs from a range of homecountry backgrounds entering one host country and industry. Focusing on one industry in one host country allows us to control for industry-specific 
effects as well as for the effects of different regulations and institutional environments. The Canadian oil and gas industry also represents an open and highly competitive market without any preferential treatment to a national oil company. The Canadian context features investing foreign SOEs and POEs from emerging economies including China, Malaysia, Thailand, and Qatar as well as from developed economies such as Norway, Japan, and South Korea (for an overview of SOE and POE origins, see Table 1). Our setting thus provides a unique opportunity to explore the importance of the home-country context for SOEs' decisions on how to enter foreign markets while controlling for a range of potential confounding factors. The actual presence of SOEs and POEs from a wide range of home countries further reduces any concerns regarding selection bias in terms of the decision whether to enter the Canadian market or not.

Data were collected from the Canoils ${ }^{\circledR}$ database, a database service provided by JuneWarren Nickle's Energy Group, which compiles details of all publicly announced mergers and acquisitions of Canadian oil and gas assets including purchase of so- called "crown assets" (JuneWarren Nickle's Energy Group, 2016). Supplementary information for the transactions identified through Canoils was collected from the Evaluate Energy ${ }^{\circledR}$ database, a service also provided by JuneWarren Nickle's Energy Group, and the companies' annual reports. Although the Canoils $^{\circledR}$ database identified transactions of several crown assets, additional data on such government lease sales was collected online via Canada's provincial governments' official publication of lease sale results to ensure that the overview was as complete as possible. The Canadian provinces publish complete lists of the announcements and subsequent results of lease sales (stand-alone assets) (Alberta Energy, 2016; BC Government, 2016; Newfoundland Department of Natural Resources, 2016). Onshore government lease sales typically include several small parcels for contiguous acres of land. These parcels may thus represent smaller parts of the same field/play. To avoid inflating the number of transactions related to government lease sales, we have therefore clustered purchases of contiguous land areas that occur over a 12-month period. This definition of "one transaction" was discussed and confirmed

Table 1 Overview of investing firms in the sample

\begin{tabular}{|c|c|c|c|c|}
\hline \multirow[t]{2}{*}{ Home country } & \multirow[t]{2}{*}{ Total number of firms } & \multirow[t]{2}{*}{ POEs } & \multicolumn{2}{|c|}{ SOEs } \\
\hline & & & Partial state ownership & $100 \%$ state ownership \\
\hline Australia & 4 & 4 & 0 & 0 \\
\hline Brazil & 1 & 1 & 0 & 0 \\
\hline China (mainland) & 4 & 1 & 2 & 1 \\
\hline China (Hong Kong) & 4 & 3 & 1 & 0 \\
\hline France & 2 & 2 & 0 & 0 \\
\hline Italy & 1 & 1 & 0 & 0 \\
\hline Japan & 3 & 2 & 1 & 0 \\
\hline Kuwait & 1 & 0 & 0 & 1 \\
\hline Libya & 1 & 0 & 0 & 1 \\
\hline Malaysia & 1 & 0 & 0 & 1 \\
\hline Netherlands & 1 & 1 & 0 & 0 \\
\hline Norway & 1 & 0 & 1 & 0 \\
\hline Poland & 1 & 0 & 1 & 0 \\
\hline Qatar & 1 & 0 & 0 & 1 \\
\hline Singapore & 1 & 1 & 0 & 0 \\
\hline South Africa & 1 & 1 & 0 & 0 \\
\hline South Korea & 4 & 1 & 1 & 2 \\
\hline Spain & 1 & 1 & 0 & 0 \\
\hline Thailand & 1 & 0 & 1 & 0 \\
\hline United Arab Emirates & 1 & 0 & 1 & 0 \\
\hline United Kingdom & 5 & 5 & 0 & 0 \\
\hline United States (USA) & 17 & 17 & 0 & 0 \\
\hline Vietnam & 1 & 1 & 0 & 0 \\
\hline Total & 58 & 42 & 9 & 7 \\
\hline
\end{tabular}


with an expert on the Canadian oil and gas industry. The 12-month period was deemed appropriate as a firm has to conduct and assess exploration activities before more informed decisions about the field can be made. At best, these activities are estimated to take at least 6 months to organize and implement. Any lease sales that occurred in contiguous areas, but with a different level of ownership (e.g., partial ownership rather than full ownership) were treated as separate transactions.

\section{Measures}

The unit of observation is the transaction. Several acquiring firms have two or more transactions during our sample period. The distinction between purchase of stand-alone assets and firms (Hypotheses $1 \mathrm{a}$ and $1 \mathrm{~b}$ ) is measured through a binary variable for deal type, with stand-alone purchases coded as 0 and firms as 1 . The choice between full ownership and joint venture (Hypotheses 2a and $2 b)$ is measured as the acquired ownership percentage of the stand-alone assets or target firms. In robustness checks, we use a categorical variable for full ownership (full ownership $=1$; otherwise $=0$ ).

Our main measure of the level of state ownership in the acquiring firm is the percentage of shares held by the home state. In a robustness check, we use a categorical variable for majority state ownership as an alternative measure taking into account threshold effects related to state ownership.

Our analysis includes two moderator variables capturing the quality of government and market orientation of the home economy, respectively. These variables have been collected from the extensive Quality of Government (QoG) dataset (Teorell, Dahlberg, Holmberg, Rothstein, Pachon \& Svensson, 2018) covering a wide range of countrylevel variables from various sources.

To measure the quality of government, we use the World Bank Governance Indicator on Government Effectiveness. This variable reflects responses on dimensions such as "the quality of public service provision, the quality of the bureaucracy, the competence of civil servants, the independence of the civil service from political pressures, and the credibility of the government's commitment to policies." (Teorell et al., 2018: 622). These dimensions are closely related to the ability of the home government to carry out appropriate SOE corporate governance including the insulation of bureaucrats from undue political pressure (Evans \& Rauch, 1999), in line with Musacchio and Lazzarini's (2014) emphasis on the need to reduce discretionary governmental interference in business decisions.

To measure the market orientation of the home context, we use the Heritage Foundation Business Freedom variable. This variable is primarily based on objective data from the World Bank's Doing Business study relating to factors such as the number of procedures, time and cost to start a business, obtain a license and close a business (Teorell et al., 2018). The Business Freedom variable also relies on data from the Economist Intelligence Unit Country Commerce, the US Department of Commerce and official government publications from each country (Miller \& Kim, 2017). The Business Freedom variable reflects the general perception of state versus private ownership in the economy, implying that for SOEs that do exist, their non-economic objectives are likely to be narrower in scope. Robustness checks consider a variety of alternative measures, some of which capture alternative institutional features.

We further include three home-country control variables: First, a dummy variable for whether the home country is a member of the Commonwealth (member $=1$, non-member $=0)$ captures home countries' links to Canada. Second, we control for the energy needs of the home country using a variable from the World Development Indicators on Energy imports: "Net energy imports are estimated as energy use less production, both measured in oil equivalents. A negative value indicates that the country is a net exporter." (Teorell et al., 2018: 646-647.) Third, GDP per capita of the homecountry (in current US\$1000, again from the World Bank Indicators) measures its development level.

We also include several control variables at the investing firm level. These controls are important to capture various characteristics of firm - beyond whether or not they are POEs or SOEs -that influence their choices of entry and establishment modes. Investing firm size is measured alternatively by revenues or by the number of employees (both transformed using the natural logarithm). We also include dummy variables for the type of investing firm, categorizing it as either Integrated (omitted baseline category), Exploration and Production $(\mathrm{E} \& \mathrm{P})$, Financial or Other. We also include a dummy variable for whether the investing firm is publicly listed. Finally, we control for the investing firm's host-country-specific experience (cf. Bass \& Chakrabarty, 2014) captured by a dummy indicating existing operations in the Canadian resource sector, as well as for its international experience 
prior to entry (cf. Slangen \& Hennart, 2007), measured by the number of countries in which the MNE had operations at the time of entry into Canada.

To account for within-industry factors, we use an indicator variable for whether the resources are conventional (value 1) or unconventional (value 0). Resources that are easily developed with conventional technology are categorized according to industry standards as conventional resources (e.g., oil found in liquid form and gas trapped in pockets of porous rocks). Resources more difficult to develop with existing technology are categorized as unconventional (e.g., shale oil and gas, oil sands, and coalbed methane) (Bass \& Chakrabarty, 2014; CAPP, 2014). Finally, transaction year dummies capture time-specific factors (Bass \& Chakrabarty, 2014), using 2010, the year with the most observations, as the omitted baseline year. Table 2 provides descriptive statistics and Table 3 the correlation matrix.

\section{ESTIMATION AND RESULTS}

The models with the binary dependent variable for the purchase of stand-alone asset versus purchase of firm are estimated by logistic regression analysis, whereas models for the percentage of shares acquired are estimated using a Tobit model given the restricted range of the dependent variable (between 10 and 100\%). Although several investing firms have multiple investments, our data do not strictly have a panel structure since we do not follow firms over time and observations are only included in the data when a transaction takes place. Moreover, many investors appear only once. Following previous studies such as Muehlfeld, Rao Sahib, \& Van Witteloostuijn (2012), we therefore pool the data, using robust standard errors clustered at the investing firm to account for withinfirm correlation. Following the approach of Meyer et al. (2014) and Karolyi \& Liao (2017), in our main analyses we enter our institutional variables in separate models since our variables for homecountry government quality (Government Effectiveness) and home-country market orientation (Business Freedom) are highly correlated $(r=0.86)$. Robustness tests address the potential omitted variables bias occasioned by this approach, finding little evidence that such a bias affects our results.

Since the choices of firm versus assets and ownership share might not be independent, we also ran additional analyses (described later) including firm versus assets in the regression for ownership share, while accounting for potential endogeneity. These analyses suggest that our results are not affected by possible links between the two dependent variables we are studying.

\section{Baseline Models}

We first present the results from the preferred specifications for our hypotheses. In all these analyses, state ownership is measured as the percentage of shares owned by the home state in the investing unit. In a later section, these results are

Table 2 Descriptive statistics

\begin{tabular}{|c|c|c|c|c|c|}
\hline & Mean & SD & Min. & Median & Max. \\
\hline Deal type $($ firm $=1)$ & 0.157 & 0.36 & 0 & 0 & 1 \\
\hline Acquisition share & 77.12 & 30.0 & 10 & 100 & 100 \\
\hline State ownership share & 24.71 & 37.5 & 0 & 0 & 100 \\
\hline Government effectiveness & 1.298 & 0.51 & -1.09 & 1.51 & 2.02 \\
\hline Business freedom & 82.38 & 15.0 & 20 & 90.8 & 95.5 \\
\hline GDP per capita & 41.52 & 17.3 & 1.16 & 46.8 & 88.3 \\
\hline Energy imports & -27.65 & 135.8 & -680.5 & 18.6 & 94.0 \\
\hline Commonwealth country & 0.174 & 0.38 & 0 & 0 & 1 \\
\hline Acquirer revenue & $97,454.3$ & $141,386.6$ & 0 & 16,809 & 552,479 \\
\hline Previous experience Canada & 0.785 & 0.41 & 0 & 1 & 1 \\
\hline Previous international experience & 11.78 & 12.0 & 0 & 6 & 52 \\
\hline Conventional production & 0.430 & 0.50 & 0 & 0 & 1 \\
\hline Listed & 0.872 & 0.33 & 0 & 1 & 1 \\
\hline Integrated & 0.632 & 0.48 & 0 & 1 & 1 \\
\hline$E \& P$ & 0.310 & 0.46 & 0 & 0 & 1 \\
\hline Financial & 0.0289 & 0.17 & 0 & 0 & 1 \\
\hline Other & 0.0289 & 0.17 & 0 & 0 & 1 \\
\hline
\end{tabular}




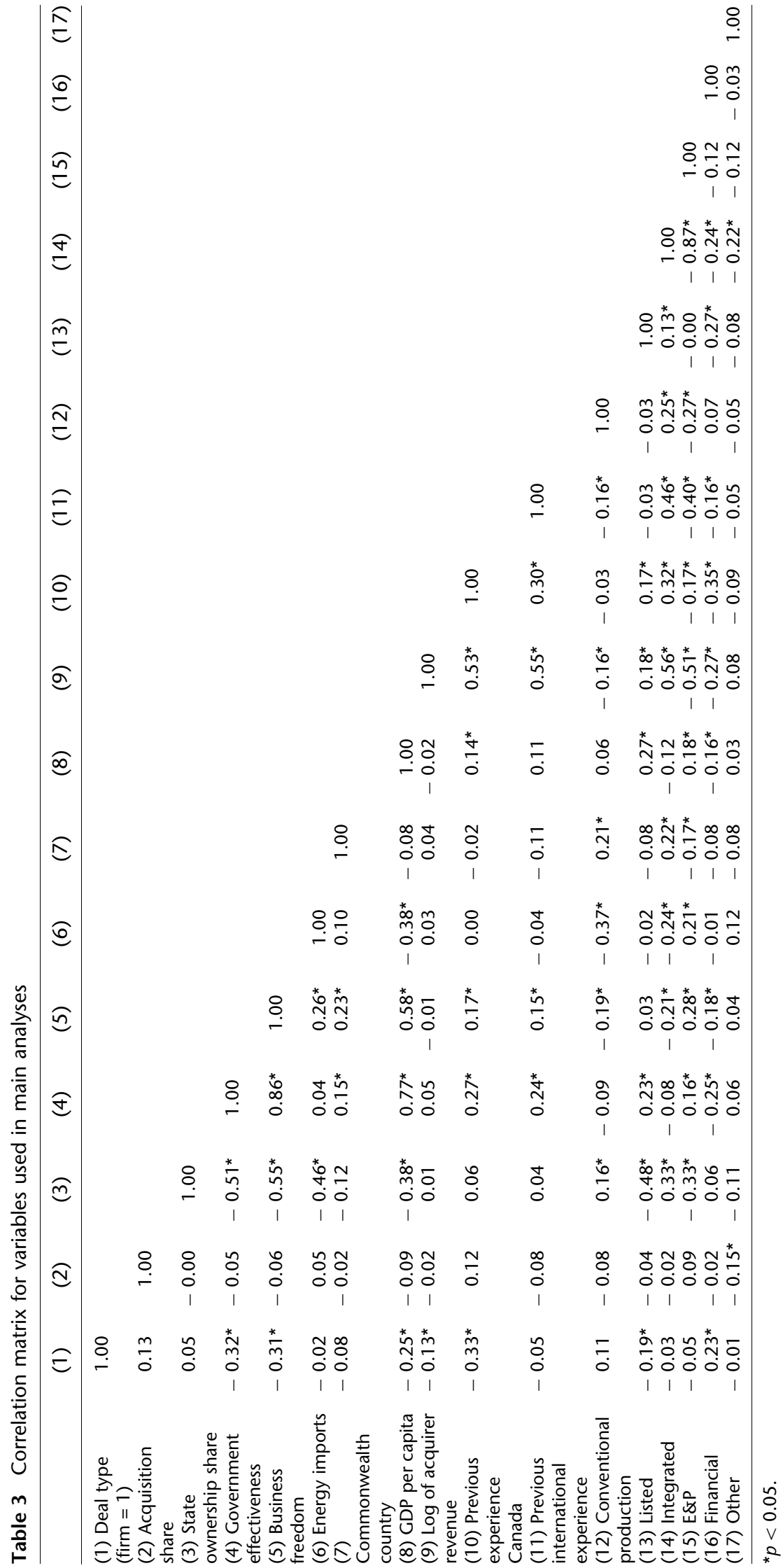



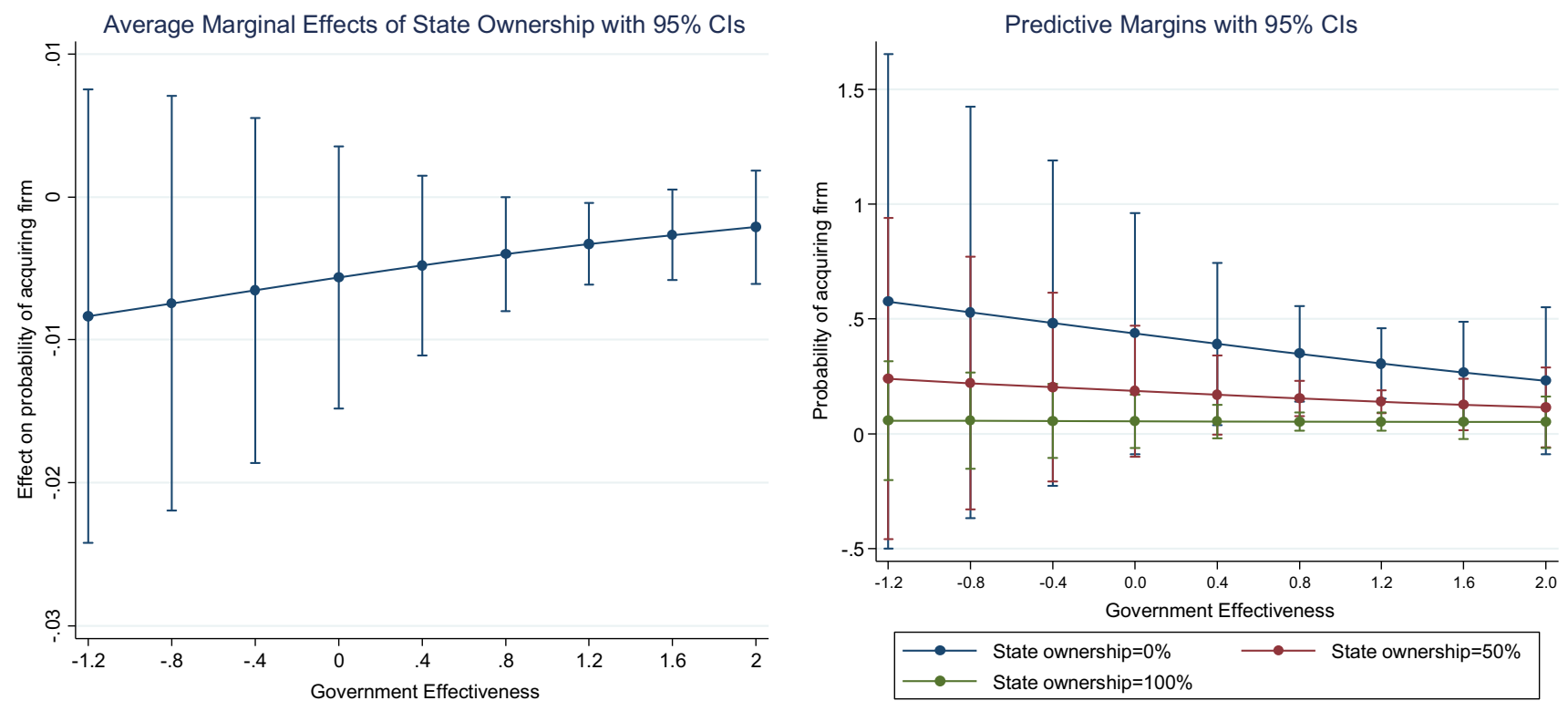

Figure 2 Average marginal effects and predictive margins for different levels of home-country government effectiveness (Hypothesis 1a).

subjected to an extensive set of robustness checks. The main results are presented in two separate tables: Table 4 contains the analyses with firm versus asset as the dependent variable, and Table 5 contains the analyses with the ownership share as the dependent variable. Each table first shows an analysis including only the control variables as well as a second analysis including the state ownership variable, but not the interaction term. With two different institutional variables analyzed in three models each, there are six models in each table. Models 1-3 in Table 4 (Table 5) are relevant for assessing H1a (H2a), and models 4-6 in Table 4 (Table 5) are relevant for H1b (H2b).

Models 2 and 5 in Table 4 without the interaction terms indicate that SOEs generally tend to choose stand-alone assets rather than firm acquisitions. Models 2 and 5 in Table 5 similarly indicate that SOEs tend to take a lower level of equity ownership. However, the interaction results discussed below will show that conclusions about general effects are inappropriate and that the results are more complex. In terms of the control variables, we note that previous experience in Canada, the home-country's energy imports, and to a lesser extent home-country GDP per capita, seem to be consistently relevant to explaining entry modes.

To test our moderation hypotheses $\mathrm{H} 1 \mathrm{a}-\mathrm{b}$ and $\mathrm{H} 2 \mathrm{a}-\mathrm{b}$ that higher quality of home-country government and more market-oriented home contexts reduce differences between SOEs and POEs in terms of their foreign entry strategies, we introduce interaction terms between the state ownership share and these home-country variables. The coefficients in Tables 4 and 5 and Figure 2 suggest that $\mathrm{H} 1 \mathrm{~b}, \mathrm{H} 2 \mathrm{a}$ and $\mathrm{H} 2 \mathrm{~b}$ are supported while $\mathrm{H} 1 \mathrm{a}$ is not. However, the interaction coefficients give only a partial understanding of the moderation effect (Kingsley, Noordewier, \& Bergh, 2017) and may be misleading for interactions in non-linear models such as Logit and Tobit models (Zelner, 2009). To better understand the interaction results, graphical analysis is particularly instructive. We consider two types of plots. First, we plot the average marginal effects (AMEs) of state ownership for different values of the home-country institutional measures to consider how the AME changes. ${ }^{5}$ Second, we plot predictions for important values of state ownership $(0,50$ and $100 \%)$. These two plots are presented for each of the four hypotheses in Figures 2, 3, 4 and 5.

The generally increasing slope of the AME curve graphed on the left-hand side in all figures broadly suggests that when the home-country context displays higher government quality and market orientation, the difference between SOEs and POEs becomes smaller and smaller. The statistical confidence in these differences can be assessed by comparing the point estimates and confidence intervals for the effects. The support for H2a and $\mathrm{H} 2 \mathrm{~b}$ is relatively clear in the sense that the point estimates for home contexts with the lowest 

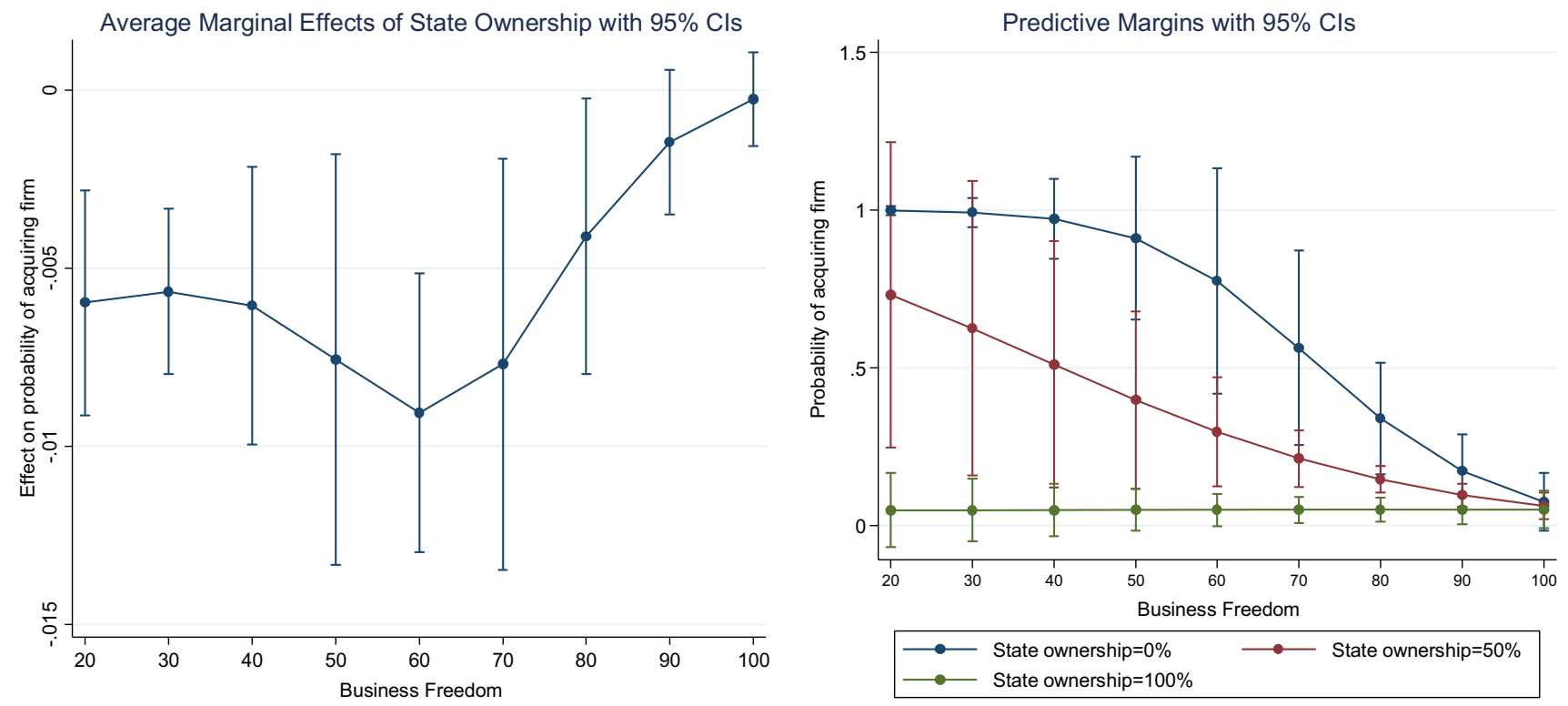

Figure 3 Average marginal effects and predictive margins for different levels of home-country business freedom (Hypothesis $1 \mathrm{~b}$ ).
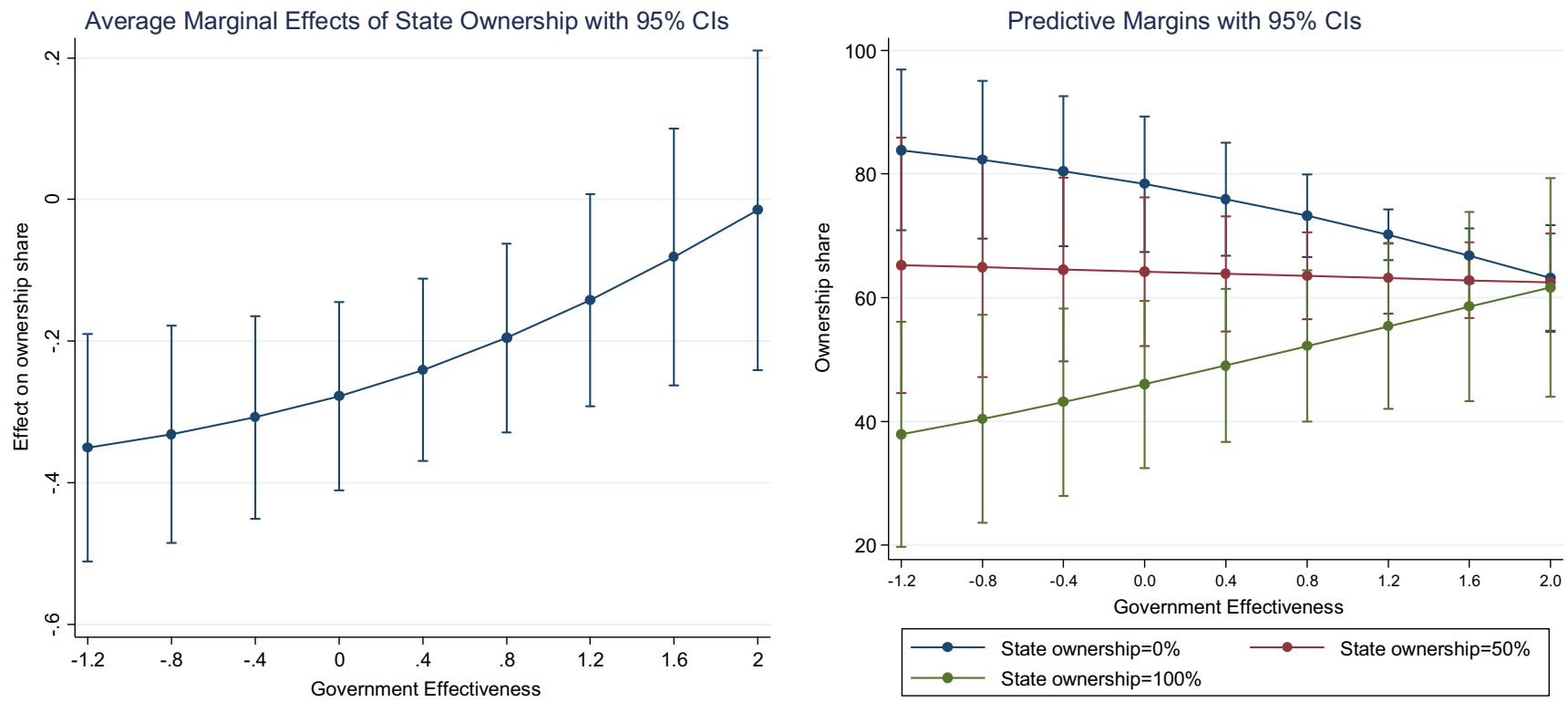

Figure 4 Average marginal effects and predictive margins for different levels of home-country government effectiveness (Hypothesis 2a).

government quality and market orientation are outside the confidence intervals of the estimates for home contexts with the highest government quality and market orientation, and vice versa. ${ }^{6}$ Indeed, for the home contexts with highest government quality the confidence intervals contain zero, suggesting the effect of state ownership is not statistically significantly different from zero. Figure 4 suggests that SOEs and POEs from countries with a score of 1.6 or above such as Norway, the
Netherlands, France (some years), and Singapore would choose very similar ownership levels.

The overlapping confidence intervals indicate there is no support for Hypothesis $1 \mathrm{a} .^{7}$ For Hypothesis $1 \mathrm{~b}$ the results are more complex, although suggesting differences between home contexts of low and high government quality. With the exception of H1a, the results seem consistent with the hypotheses, with the effect of state ownership tending towards zero as home-country government 

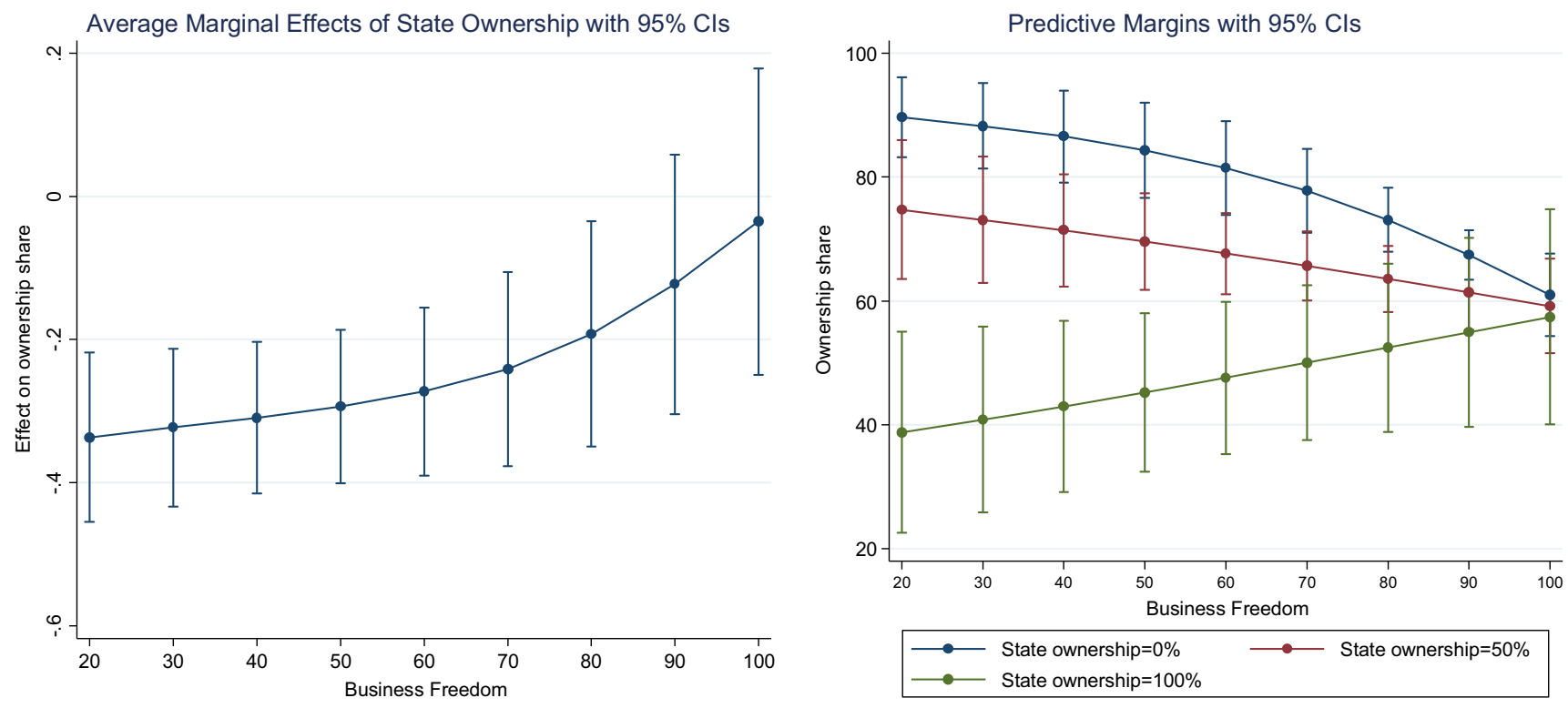

Figure 5 Average marginal effects and predictive margins for different levels of investing firm home-country business freedom (Hypothesis 2b).

quality and market orientation increase. Figure 3 suggests that SOEs and POEs make very similar establishment mode decisions for values of business freedom of 90 and beyond (including home countries like Norway, UK, South Korea, and Singapore).

Even more illuminating, however, is to consider predictions for selected key levels of state ownership (0\% - i.e., fully POEs, $50 \%$ state ownership i.e., hybrid SOEs, and $100 \%$ state ownership, i.e., fully SOEs). ${ }^{8}$ The graphs on the right hand side of Figures 2 and 3 indicate that POEs from home contexts with low government quality and market orientation have a high probability of acquiring a firm, while either partly SOEs or fully SOEs display substantially lower probabilities. However, as home government quality and market orientation increase, the various types of firms converge in their strategies. There are various degrees of overlap between the confidence intervals for the three different categories of firms and the graphs, which suggests that differences across home contexts are only statistically significant for market orientation. These graphs reveal that POEs and partly SOEs both display a lower probability of acquiring a firm, but interestingly, fully SOEs seem to be mostly unaffected by the home-country context. One possible interpretation is that fully SOEs remain key agents of home governments' goals in terms of resource security, and are not affected by the same factors that determine POEs' or partly SOEs' choices, including potential differences in FSAs related to the home context.

Figures 4 and 5 relating to the ownership share indicate a pattern whereby POEs from home contexts with low government quality take higher ownership shares than either partly SOEs or fully SOEs, with a similar pattern of convergence based on the home-country context. Although there are again various degrees of overlap between the confidence intervals of the three categories, the differences appear statistically significant. In this case, fully SOEs from home contexts with higher government quality and market orientation take higher ownership shares.

\section{Robustness Checks}

We run various robustness checks on our baseline results (tables and graphs are available on request). First, running ordinary least squares (OLS) models largely reproduce the results, but with some differences. Specifically, for the choice of acquiring firms versus stand-alone assets we find $\mathrm{H1a}$ is not supported while $\mathrm{H} 1 \mathrm{~b}$ is, whereas using an OLS model for the acquisition share analyses rather than Tobit now only H2b is supported (5\% level). Second, using a dummy variable for wholly owned investment projects rather than the target ownership percentage and running logistic regression (using either 100, 95, or 90\% ownership cutoffs for classifying wholly owned) still supports $\mathrm{H} 2 \mathrm{a}$ and 
Table 4 Logit regression results for Hypotheses $\mathrm{H} 1 \mathrm{a}-\mathrm{H} 1 \mathrm{~b}$ explaining acquisition of firm versus assets

\begin{tabular}{|c|c|c|c|c|c|c|}
\hline & $\begin{array}{l}\text { (1) } \\
\text { Model with } \\
\text { controls }\end{array}$ & $\begin{array}{l}(2) \\
\text { Baseline } \\
\text { model }\end{array}$ & $\begin{array}{l}(3) \\
\text { Interaction } \\
\text { model }\end{array}$ & $\begin{array}{l}\text { (4) } \\
\text { Model with } \\
\text { controls }\end{array}$ & $\begin{array}{l}(5) \\
\text { Baseline } \\
\text { model }\end{array}$ & $\begin{array}{l}(6) \\
\text { Interaction } \\
\text { model }\end{array}$ \\
\hline State ownership & & $\begin{array}{l}-0.038 \\
(0.014) \\
{[0.008]}\end{array}$ & $\begin{array}{l}-0.045 \\
(0.019) \\
{[0.020]}\end{array}$ & & $\begin{array}{l}-0.039 \\
(0.015) \\
{[0.009]}\end{array}$ & $\begin{array}{l}-0.153 \\
(0.054) \\
{[0.005]}\end{array}$ \\
\hline Government effectiveness & $\begin{array}{l}-0.662 \\
(1.313) \\
{[0.614]}\end{array}$ & $\begin{array}{l}-0.506 \\
(1.435) \\
{[0.724]}\end{array}$ & $\begin{array}{l}-0.884 \\
(1.596) \\
{[0.580]}\end{array}$ & & & \\
\hline Business freedom & & & & $\begin{array}{l}-0.041 \\
(0.025) \\
{[0.095]}\end{array}$ & $\begin{array}{l}-0.044 \\
(0.024) \\
{[0.071]}\end{array}$ & $\begin{array}{l}-0.146 \\
(0.049) \\
{[0.003]}\end{array}$ \\
\hline $\begin{array}{l}\text { H1a: State ownership } \times \text { government } \\
\text { effectiveness }\end{array}$ & & & $\begin{array}{l}0.008 \\
(0.015) \\
{[0.588]}\end{array}$ & & & \\
\hline $\begin{array}{l}\mathrm{H} 1 \mathrm{~b} \text { : State ownership } \times \text { business } \\
\text { freedom }\end{array}$ & & & & & & $\begin{array}{l}0.001 \\
(0.001) \\
{[0.017]}\end{array}$ \\
\hline Energy imports & $\begin{array}{l}-0.000 \\
(0.002) \\
{[0.897]}\end{array}$ & $\begin{array}{l}-0.007 \\
(0.003) \\
{[0.008]}\end{array}$ & $\begin{array}{l}-0.006 \\
(0.003) \\
{[0.038]}\end{array}$ & $\begin{array}{l}0.002 \\
(0.002) \\
{[0.512]}\end{array}$ & $\begin{array}{l}-0.005 \\
(0.003) \\
{[0.055]}\end{array}$ & $\begin{array}{l}-0.003 \\
(0.003) \\
{[0.307]}\end{array}$ \\
\hline Commonwealth country & $\begin{array}{l}-0.736 \\
(0.872) \\
{[0.398]}\end{array}$ & $\begin{array}{l}-1.562 \\
(0.928) \\
{[0.092]}\end{array}$ & $\begin{array}{l}-1.512 \\
(0.942) \\
{[0.108]}\end{array}$ & $\begin{array}{l}-0.591 \\
(0.745) \\
{[0.428]}\end{array}$ & $\begin{array}{l}-1.300 \\
(0.798) \\
{[0.103]}\end{array}$ & $\begin{array}{l}-0.895 \\
(0.785) \\
{[0.254]}\end{array}$ \\
\hline GDP per capita & $\begin{array}{l}-0.032 \\
(0.039) \\
{[0.418]}\end{array}$ & $\begin{array}{l}-0.080 \\
(0.049) \\
{[0.104]}\end{array}$ & $\begin{array}{l}-0.075 \\
(0.052) \\
{[0.154]}\end{array}$ & $\begin{array}{l}-0.020 \\
(0.026) \\
{[0.452]}\end{array}$ & $\begin{array}{l}-0.063 \\
(0.031) \\
{[0.046]}\end{array}$ & $\begin{array}{l}-0.030 \\
(0.032) \\
{[0.345]}\end{array}$ \\
\hline Log of acquirer revenue & $\begin{array}{l}-0.089 \\
(0.117) \\
{[0.444]}\end{array}$ & $\begin{array}{l}-0.129 \\
(0.127) \\
{[0.312]}\end{array}$ & $\begin{array}{l}-0.112 \\
(0.140) \\
{[0.425]}\end{array}$ & $\begin{array}{l}-0.097 \\
(0.102) \\
{[0.343]}\end{array}$ & $\begin{array}{l}-0.136 \\
(0.118) \\
{[0.247]}\end{array}$ & $\begin{array}{l}-0.086 \\
(0.142) \\
{[0.547]}\end{array}$ \\
\hline Experience Canada & $\begin{array}{l}-1.598 \\
(0.632) \\
{[0.011]}\end{array}$ & $\begin{array}{l}-0.956 \\
(0.663) \\
{[0.149]}\end{array}$ & $\begin{array}{l}-0.960 \\
(0.668) \\
{[0.150]}\end{array}$ & $\begin{array}{l}-1.649 \\
(0.632) \\
{[0.009]}\end{array}$ & $\begin{array}{l}-0.989 \\
(0.633) \\
{[0.118]}\end{array}$ & $\begin{array}{l}-1.088 \\
(0.633) \\
{[0.085]}\end{array}$ \\
\hline International experience & $\begin{array}{l}0.038 \\
(0.038) \\
{[0.327]}\end{array}$ & $\begin{array}{l}0.028 \\
(0.036) \\
{[0.435]}\end{array}$ & $\begin{array}{l}0.027 \\
(0.037) \\
{[0.466]}\end{array}$ & $\begin{array}{l}0.041 \\
(0.031) \\
{[0.183]}\end{array}$ & $\begin{array}{l}0.032 \\
(0.032) \\
{[0.312]}\end{array}$ & $\begin{array}{l}0.020 \\
(0.031) \\
{[0.517]}\end{array}$ \\
\hline Conventional production & $\begin{array}{l}0.870 \\
(0.572) \\
{[0.128]}\end{array}$ & $\begin{array}{l}0.617 \\
(0.597) \\
{[0.301]}\end{array}$ & $\begin{array}{l}0.611 \\
(0.609) \\
{[0.315]}\end{array}$ & $\begin{array}{l}0.785 \\
(0.586) \\
{[0.180]}\end{array}$ & $\begin{array}{l}0.455 \\
(0.641) \\
{[0.478]}\end{array}$ & $\begin{array}{l}0.379 \\
(0.680) \\
{[0.577]}\end{array}$ \\
\hline Listed & $\begin{array}{l}-1.042 \\
(0.666) \\
{[0.118]}\end{array}$ & $\begin{array}{l}-2.968 \\
(1.173) \\
{[0.011]}\end{array}$ & $\begin{array}{l}-2.851 \\
(1.149) \\
{[0.013]}\end{array}$ & $\begin{array}{l}-1.360 \\
(0.648) \\
{[0.036]}\end{array}$ & $\begin{array}{l}-3.264 \\
(1.199) \\
{[0.006]}\end{array}$ & $\begin{array}{l}-3.038 \\
(0.997) \\
{[0.002]}\end{array}$ \\
\hline$E \& P$ & $\begin{array}{l}-0.484 \\
(0.725) \\
{[0.505]}\end{array}$ & $\begin{array}{l}-1.236 \\
(0.973) \\
{[0.204]}\end{array}$ & $\begin{array}{l}-1.178 \\
(0.944) \\
{[0.212]}\end{array}$ & $\begin{array}{l}-0.406 \\
(0.763) \\
{[0.595]}\end{array}$ & $\begin{array}{l}-1.164 \\
(1.035) \\
{[0.261]}\end{array}$ & $\begin{array}{l}-1.052 \\
(0.964) \\
{[0.275]}\end{array}$ \\
\hline Financial & $\begin{array}{l}0.311 \\
(1.256) \\
{[0.804]}\end{array}$ & $\begin{array}{l}-0.095 \\
(1.549) \\
{[0.951]}\end{array}$ & $\begin{array}{l}0.082 \\
(1.531) \\
{[0.957]}\end{array}$ & $\begin{array}{l}0.171 \\
(1.303) \\
{[0.896]}\end{array}$ & $\begin{array}{l}-0.272 \\
(1.758) \\
{[0.877]}\end{array}$ & $\begin{array}{l}0.296 \\
(1.366) \\
{[0.829]}\end{array}$ \\
\hline Other & $\begin{array}{l}0.876 \\
(1.592) \\
{[0.582]}\end{array}$ & $\begin{array}{l}-0.320 \\
(2.489) \\
{[0.898]}\end{array}$ & $\begin{array}{l}-0.225 \\
(2.396) \\
{[0.925]}\end{array}$ & $\begin{array}{l}0.811 \\
(1.409) \\
{[0.565]}\end{array}$ & $\begin{array}{l}-0.464 \\
(2.545) \\
{[0.855]}\end{array}$ & $\begin{array}{l}-0.387 \\
(1.984) \\
{[0.845]}\end{array}$ \\
\hline Constant & $\begin{array}{l}0.830 \\
(1.506) \\
{[0.581]}\end{array}$ & $\begin{array}{l}5.360 \\
(2.617) \\
{[0.041]}\end{array}$ & $\begin{array}{l}5.393 \\
(2.614) \\
{[0.039]}\end{array}$ & $\begin{array}{l}3.399 \\
(2.269) \\
{[0.134]}\end{array}$ & $\begin{array}{l}8.171 \\
(3.264) \\
{[0.012]}\end{array}$ & $\begin{array}{l}15.192 \\
(4.917) \\
{[0.002]}\end{array}$ \\
\hline
\end{tabular}




\begin{tabular}{|c|c|c|c|c|c|c|}
\hline & $\begin{array}{l}(1) \\
\text { Model with } \\
\text { controls }\end{array}$ & $\begin{array}{l}(2) \\
\text { Baseline } \\
\text { model }\end{array}$ & $\begin{array}{l}(3) \\
\text { Interaction } \\
\text { model }\end{array}$ & $\begin{array}{l}\text { (4) } \\
\text { Model with } \\
\text { controls }\end{array}$ & $\begin{array}{l}(5) \\
\text { Baseline } \\
\text { model }\end{array}$ & $\begin{array}{l}(6) \\
\text { Interaction } \\
\text { model }\end{array}$ \\
\hline$N$ & 244 & 244 & 244 & 244 & 244 & 244 \\
\hline Log-likelihood & -74.99 & -69.88 & -69.75 & -73.97 & -68.71 & -65.87 \\
\hline Pseudo $R$-squared & 0.30 & 0.35 & 0.35 & 0.31 & 0.36 & 0.39 \\
\hline 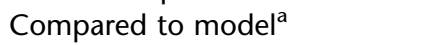 & & (1) & $(2)$ & & (4) & (5) \\
\hline Likelihood ratio Chi-square $(1)^{\mathrm{a}}$ & & 10.21 & 0.27 & & 10.52 & 5.68 \\
\hline$p$ value of likelihood ratio test ${ }^{a}$ & & 0.0014 & 0.6056 & & 0.0012 & 0.0171 \\
\hline
\end{tabular}

Robust clustered standard errors in parentheses and $p$ values in brackets. Year dummies included in analysis but omitted from table.

${ }^{a}$ Likelihood ratio tests based on auxiliary analyses without robust clustered standard errors as Stata 14 does not support the LR tests when robust clustered standard errors are included.
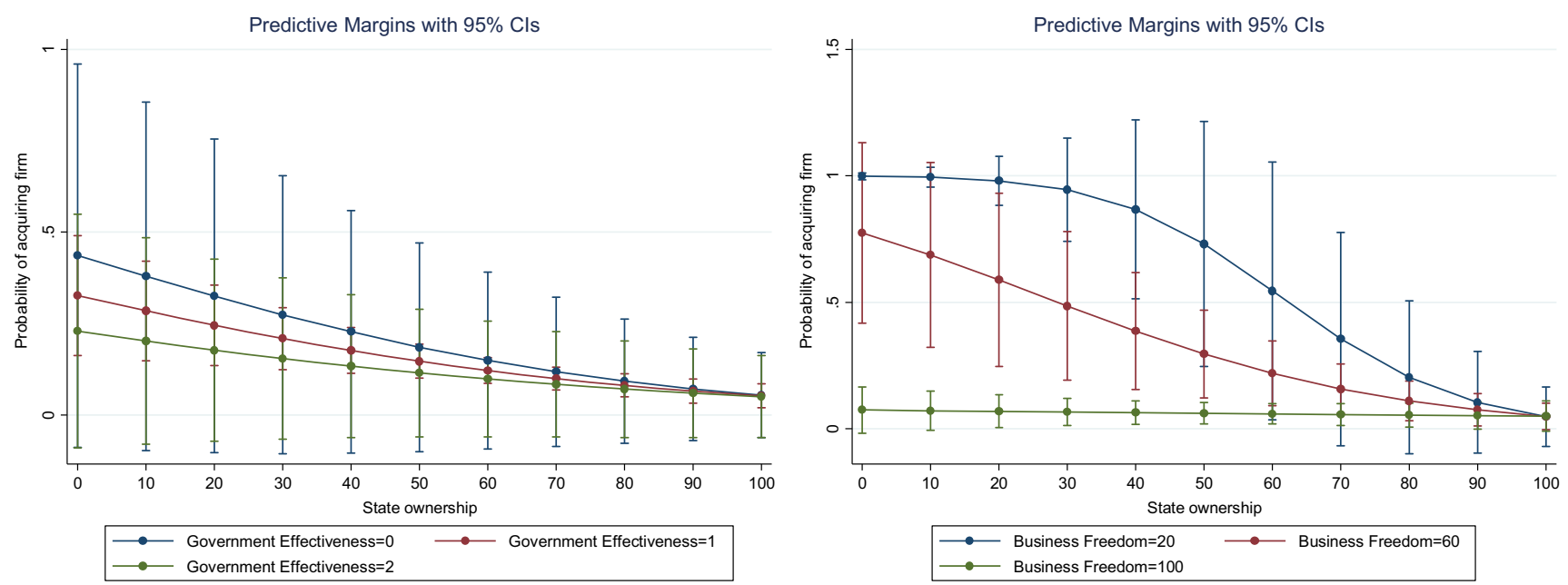

Figure 6 Predictive margins for different levels of state ownership (Hypothesis 1a-b).

H2b. Third, replacing the (natural logarithm of) revenues with the (natural logarithm of the) number of employees as our measure of investing firm size supports $\mathrm{H} 1 \mathrm{~b}, \mathrm{H} 2 \mathrm{a}$ and $\mathrm{H} 2 \mathrm{~b}$ intact, while $\mathrm{H} 1 \mathrm{a}$ is still unsupported. Fourth, replacing the state ownership share with a dummy for majority state ownership does not support $\mathrm{H} 1 \mathrm{a}$ or $\mathrm{H} 1 \mathrm{~b}$, while it supports $\mathrm{H} 2 \mathrm{a}$ and $\mathrm{H} 2 \mathrm{~b}$. Fifth, addressing the issue of multicollinearity versus omitted variable bias regarding our two institutional variables, we initially estimate models controlling for the other institutional variable, finding the interaction results to be very similar despite potential multicollinearity. Including both interactions $\mathrm{H} 1 \mathrm{a}$ and H1b still receive marginal support. However, in the model for $\mathrm{H} 2 \mathrm{a}$ and $\mathrm{H} 2 \mathrm{~b}$ both interactions lose significance, likely due to high collinearity. To address this, we follow Karolyi \& Liao (2017) and extract the first principal component of the institutional variables, introducing this as a new variable in our analysis replacing the two institutional variables. The combined institutional measure produces similar results as using each measure separately, indicating that strong government quality and market-oriented institutions together induce SOEs and POEs to behave similarly in their foreign entries.

Sixth, we also tested a variety of other institutional variables. A first category is alternative measures of our main theoretical concepts. The World Bank Governance Indicator for Regulatory Quality produces qualitatively similar, although much less clear results, than our main government quality measure. Using the Fraser Institute measures for Size of Government (measuring the role of the government in the home economy in various ways) and Economic Freedom however produces very strong and significant support for our 



Figure 7 Predictive margins for different levels of state ownership (Hypothesis 2a-b).

hypotheses. A second category of institutional variables are not directly related to our theoretical concepts but of interest by themselves. First, World Bank Governance Indicators for Rule of Law or Control of Corruption produce similar, although again considerably weaker, results. To assess the role of the overall quality of the institutional environment, a factor of all six World Governance Indicators (cf. Cannizzaro \& Weiner, 2018) gives broadly qualitatively similar results to our key measures, although again weaker. Additionally, neither the broader concept of Democracy as measured by the Polity Index nor country risk as measured by the International Country Risk Guide (ICRG) (cf. Clegg et al., 2018), seem to have an important influence on the difference between SOE and POE entry modes. It is worth noting that the second category of institutional variables is relatively far removed from our theoretical arguments. As such, the generally weak results for these alternative variables compared to our main results could be seen to suggest that an overall concept of institutional quality is less relevant than our more specific concepts, especially for market orientation.

Seventh, we produce a complementary set of graphs based on the idea that considering both sides of an interaction can provide a stronger test of the theory (Berry, Golder, \& Milton, 2012). Specifically, it is also possible to test $\mathrm{H} 1 \mathrm{a}-\mathrm{b}$ and $\mathrm{H} 2 \mathrm{a}-\mathrm{b}$ by deriving predictions for increasing state ownership for various levels of home-country government quality and market orientation. From this perspective, our expectation would be that state ownership has a diverging effect for home contexts of low government quality and market orientation, while we would expect convergence for home contexts of high government quality and market orientation. Indeed, this is clearly what is suggested by Figures 6 and 7 as in contexts with high government quality and market orientation, state ownership has very little effect.

Eighth and lastly, although our main analyses consider the choice between firms and assets and the choice of ownership share in the transaction separately, these choices could be related. In particular, the choice between firm and assets could influence the desired ownership share. To check the robustness of our results, we therefore run additional analyses where we include the firm versus assets dummy in the regression for ownership share. Given the potential for endogeneity, we run two stages least squares (2SLS) analyses. In the model for ownership share, we instrument for firms versus assets using a dummy for whether there was existing production in the investment object or not, and another dummy for whether the investing firm has previous experience in unconventional technologies. The two instruments jointly pass the test of instrument relevance (above $F=25$ in the first stage, exceeding the suggested threshold of 11.59 for two instruments in Stock, Wright, \& Yogo, 2002), as well as the overidentifying restrictions tests (Sargan \& Basmann tests, although just marginally in the case for $\mathrm{H} 2 \mathrm{~b}$ where $p=0.099$ for the Sargan test). For both models, the post hoc tests of endogeneity suggest no endogeneity (Durbin \& Wu-Hausman tests have $p$ values $>0.9$ ). There is also no indication that the choice between firms and assets has a bearing on the choice of ownership level, while the 2SLS results are comparable to those 
Table 5 Tobit regression results for Hypotheses $\mathrm{H} 2 \mathrm{a}$ and $\mathrm{H} 2 \mathrm{~b}$ explaining ownership levels

\begin{tabular}{|c|c|c|c|c|c|c|}
\hline & $\begin{array}{l}\text { (1) } \\
\text { Model with } \\
\text { controls }\end{array}$ & $\begin{array}{l}(2) \\
\text { Baseline } \\
\text { model }\end{array}$ & $\begin{array}{l}(3) \\
\text { Interaction } \\
\text { model }\end{array}$ & $\begin{array}{l}\text { (4) } \\
\text { Model with } \\
\text { controls }\end{array}$ & $\begin{array}{l}(5) \\
\text { Baseline } \\
\text { model }\end{array}$ & $\begin{array}{l}(6) \\
\text { Interaction } \\
\text { model }\end{array}$ \\
\hline State ownership & & $\begin{array}{l}-1.02 \\
(0.43) \\
{[0.017]}\end{array}$ & $\begin{array}{l}-2.12 \\
(0.54) \\
{[0.000]}\end{array}$ & & $\begin{array}{l}-1.06 \\
(0.46) \\
{[0.021]}\end{array}$ & $\begin{array}{l}-5.51 \\
(1.60) \\
{[0.001]}\end{array}$ \\
\hline Government effectiveness & $\begin{array}{l}12.81 \\
(26.70) \\
{[0.632]}\end{array}$ & $\begin{array}{l}10.40 \\
(25.44) \\
{[0.683]}\end{array}$ & $\begin{array}{l}-56.16 \\
(37.16) \\
{[0.132]}\end{array}$ & & & \\
\hline Business freedom & & & & $\begin{array}{l}0.07 \\
(0.70) \\
{[0.924]}\end{array}$ & $\begin{array}{l}-0.30 \\
(0.75) \\
{[0.692]}\end{array}$ & $\begin{array}{l}-3.92 \\
(1.39) \\
{[0.005]}\end{array}$ \\
\hline $\begin{array}{l}\text { H2a: State ownership } \times \text { government } \\
\text { effectiveness }\end{array}$ & & & $\begin{array}{l}1.02 \\
(0.44) \\
{[0.022]}\end{array}$ & & & \\
\hline $\begin{array}{l}\mathrm{H} 2 \mathrm{~b} \text { : State ownership } \times \text { business } \\
\text { freedom }\end{array}$ & & & & & & $\begin{array}{l}0.05 \\
(0.02) \\
{[0.005]}\end{array}$ \\
\hline Energy imports & $\begin{array}{l}-0.06 \\
(0.04) \\
{[0.165]}\end{array}$ & $\begin{array}{l}-0.24 \\
(0.08) \\
{[0.004]}\end{array}$ & $\begin{array}{l}-0.18 \\
(0.10) \\
{[0.073]}\end{array}$ & $\begin{array}{l}-0.05 \\
(0.04) \\
{[0.212]}\end{array}$ & $\begin{array}{l}-0.22 \\
(0.07) \\
{[0.003]}\end{array}$ & $\begin{array}{l}-0.19 \\
(0.09) \\
{[0.027]}\end{array}$ \\
\hline Commonwealth country & $\begin{array}{l}-10.86 \\
(17.57) \\
{[0.537]}\end{array}$ & $\begin{array}{l}-27.11 \\
(17.18) \\
{[0.116]}\end{array}$ & $\begin{array}{l}-10.72 \\
(18.25) \\
{[0.558]}\end{array}$ & $\begin{array}{l}-7.15 \\
(17.48) \\
{[0.683]}\end{array}$ & $\begin{array}{l}-20.98 \\
(16.60) \\
{[0.208]}\end{array}$ & $\begin{array}{l}-6.08 \\
(14.53) \\
{[0.676]}\end{array}$ \\
\hline GDP per capita & $\begin{array}{l}-0.95 \\
(0.79) \\
{[0.235]}\end{array}$ & $\begin{array}{l}-2.12 \\
(0.79) \\
{[0.008]}\end{array}$ & $\begin{array}{l}-1.51 \\
(0.90) \\
{[0.094]}\end{array}$ & $\begin{array}{l}-0.70 \\
(0.65) \\
{[0.288]}\end{array}$ & $\begin{array}{l}-1.75 \\
(0.65) \\
{[0.008]}\end{array}$ & $\begin{array}{l}-1.25 \\
(0.78) \\
{[0.112]}\end{array}$ \\
\hline Log of acquirer revenue & $\begin{array}{l}-0.66 \\
(3.04) \\
{[0.827]}\end{array}$ & $\begin{array}{l}-1.93 \\
(3.05) \\
{[0.526]}\end{array}$ & $\begin{array}{l}-1.43 \\
(2.92) \\
{[0.625]}\end{array}$ & $\begin{array}{l}-1.13 \\
(3.07) \\
{[0.714]}\end{array}$ & $\begin{array}{l}-2.63 \\
(3.10) \\
{[0.398]}\end{array}$ & $\begin{array}{l}-1.28 \\
(2.80) \\
{[0.647]}\end{array}$ \\
\hline Experience Canada & $\begin{array}{l}28.34 \\
(17.75) \\
{[0.112]}\end{array}$ & $\begin{array}{l}42.34 \\
(17.98) \\
{[0.019]}\end{array}$ & $\begin{array}{l}49.19 \\
(17.91) \\
{[0.007]}\end{array}$ & $\begin{array}{l}31.10 \\
(17.11) \\
{[0.070]}\end{array}$ & $\begin{array}{l}46.38 \\
(17.49) \\
{[0.009]}\end{array}$ & $\begin{array}{l}49.55 \\
(17.20) \\
{[0.004]}\end{array}$ \\
\hline International experience & $\begin{array}{l}-0.63 \\
(1.01) \\
{[0.535]}\end{array}$ & $\begin{array}{l}-0.95 \\
(0.97) \\
{[0.329]}\end{array}$ & $\begin{array}{l}-0.75 \\
(1.04) \\
{[0.472]}\end{array}$ & $\begin{array}{l}-0.49 \\
(1.04) \\
{[0.639]}\end{array}$ & $\begin{array}{l}-0.77 \\
(0.96) \\
{[0.427]}\end{array}$ & $\begin{array}{l}-1.29 \\
(0.91) \\
{[0.158]}\end{array}$ \\
\hline Conventional production & $\begin{array}{l}-12.45 \\
(14.04) \\
{[0.376]}\end{array}$ & $\begin{array}{l}-18.31 \\
(13.09) \\
{[0.163]}\end{array}$ & $\begin{array}{l}-21.20 \\
(12.31) \\
{[0.086]}\end{array}$ & $\begin{array}{l}-12.74 \\
(14.30) \\
{[0.374]}\end{array}$ & $\begin{array}{l}-19.53 \\
(13.38) \\
{[0.146]}\end{array}$ & $\begin{array}{l}-23.21 \\
(12.96) \\
{[0.075]}\end{array}$ \\
\hline Listed & $\begin{array}{l}-13.21 \\
(25.14) \\
{[0.600]}\end{array}$ & $\begin{array}{l}-62.10 \\
(30.39) \\
{[0.042]}\end{array}$ & $\begin{array}{l}-51.81 \\
(28.61) \\
{[0.072]}\end{array}$ & $\begin{array}{l}-11.72 \\
(25.79) \\
{[0.650]}\end{array}$ & $\begin{array}{l}-64.49 \\
(31.08) \\
{[0.039]}\end{array}$ & $\begin{array}{l}-61.21 \\
(29.71) \\
{[0.041]}\end{array}$ \\
\hline$E \& P$ & $\begin{array}{l}10.07 \\
(20.94) \\
{[0.631]}\end{array}$ & $\begin{array}{l}-9.88 \\
(20.31) \\
{[0.627]}\end{array}$ & $\begin{array}{l}-3.66 \\
(20.54) \\
{[0.859]}\end{array}$ & $\begin{array}{l}10.50 \\
(21.04) \\
{[0.618]}\end{array}$ & $\begin{array}{l}-8.98 \\
(19.85) \\
{[0.652]}\end{array}$ & $\begin{array}{l}-8.44 \\
(19.18) \\
{[0.661]}\end{array}$ \\
\hline Financial & $\begin{array}{l}-9.72 \\
(41.48) \\
{[0.815]}\end{array}$ & $\begin{array}{l}-40.89 \\
(40.41) \\
{[0.313]}\end{array}$ & $\begin{array}{l}-4.57 \\
(46.57) \\
{[0.922]}\end{array}$ & $\begin{array}{l}-10.19 \\
(41.41) \\
{[0.806]}\end{array}$ & $\begin{array}{l}-42.92 \\
(40.29) \\
{[0.288]}\end{array}$ & $\begin{array}{l}-13.16 \\
(44.51) \\
{[0.768]}\end{array}$ \\
\hline Other & $\begin{array}{l}-41.81 \\
(34.72) \\
{[0.230]}\end{array}$ & $\begin{array}{l}-59.52 \\
(25.65) \\
{[0.021]}\end{array}$ & $\begin{array}{l}-52.97 \\
(26.44) \\
{[0.046]}\end{array}$ & $\begin{array}{l}-38.00 \\
(34.70) \\
{[0.275]}\end{array}$ & $\begin{array}{l}-55.50 \\
(26.14) \\
{[0.035]}\end{array}$ & $\begin{array}{l}-67.47 \\
(31.52) \\
{[0.033]}\end{array}$ \\
\hline Constant & $\begin{array}{l}125.12 \\
(43.55) \\
{[0.004]}\end{array}$ & $\begin{array}{l}255.29 \\
(55.59) \\
{[0.000]}\end{array}$ & $\begin{array}{l}297.07 \\
(58.25) \\
{[0.000]}\end{array}$ & $\begin{array}{l}125.27 \\
(57.22) \\
{[0.030]}\end{array}$ & $\begin{array}{l}283.73 \\
(78.59) \\
{[0.000]}\end{array}$ & $\begin{array}{l}570.72 \\
(136.02) \\
{[0.000]}\end{array}$ \\
\hline
\end{tabular}


Table 5 (Continued)

\begin{tabular}{|c|c|c|c|c|c|c|}
\hline & $\begin{array}{l}(1) \\
\text { Model with } \\
\text { controls }\end{array}$ & $\begin{array}{l}(2) \\
\text { Baseline } \\
\text { model }\end{array}$ & $\begin{array}{l}(3) \\
\text { Interaction } \\
\text { model }\end{array}$ & $\begin{array}{l}(4) \\
\text { Model with } \\
\text { controls }\end{array}$ & $\begin{array}{l}(5) \\
\text { Baseline } \\
\text { model }\end{array}$ & $\begin{array}{l}(6) \\
\text { Interaction } \\
\text { model }\end{array}$ \\
\hline$N$ & 243 & 243 & 243 & 243 & 243 & 243 \\
\hline Log-likelihood & -603.96 & -598.47 & -594.88 & -604.12 & -598.46 & -593.02 \\
\hline Pseudo $R$-squared & 0.03 & 0.03 & 0.04 & 0.03 & 0.03 & 0.04 \\
\hline Compared to model ${ }^{\mathrm{a}}$ & & (1) & (2) & & (4) & (5) \\
\hline Likelihood ratio Chi-square $(1)^{a}$ & & 10.99 & 7.18 & & 11.32 & 10.89 \\
\hline$p$ value of likelihood ratio test ${ }^{a}$ & & 0.0009 & 0.0074 & & 0.0008 & 0.0010 \\
\hline
\end{tabular}

Robust clustered standard errors in parentheses and $p$ values in brackets. Year dummies included in analysis but omitted from table.

a Likelihood ratio tests based on auxiliary analyses without robust clustered standard errors as Stata 14 does not support the LR tests when robust clustered standard errors are included.

from the OLS analyses reported above. We take this to imply that our baseline analyses for $\mathrm{H} 2 \mathrm{a}-\mathrm{b}$ without the additional variable are adequate and retain these for parsimony.

Overall, the main message from the results is that the effect of ownership depends crucially on homecountry context. SOEs from countries with low government effectiveness and business freedom tend to take lower ownership shares. However, as government effectiveness and business freedom increases, SOEs and POEs become more and more alike. There is also some evidence that SOEs tend to target stand-alone assets, a tendency that is weakened when business freedom in the home-country increases.

\section{DISCUSSION AND CONCLUSION}

Internalization theory was developed to answer the question of why MNEs exist, in an era where most MNEs originated in Western countries, and were characterized by profit seeking (if not necessarily profit maximizing) behavior. The domain of internalization theory was later extended beyond the choice between FDI and modes such as licensing, to explain FDI-related decisions such as full ownership versus joint venture (Brouthers \& Hennart, 2007), greenfield versus acquisition (Slangen \& Hennart, 2007), and even intra-MNE governance of subsidiaries (e.g., Buckley \& Strange, 2011). Currently, the global economy is more diverse, including digital firms, family firms, and the phenomenon discussed in this paper, SOEs, which play an increasingly important role in the global economy (OECD, 2014). The question is whether internalization theory is able to accommodate this diversity of MNEs.

In this study, we explore the applicability of internalization theory to SOEs. With the traditional focus on internalization theory on profit-maximizing firms, it has been claimed that SOE behavior is outside the domain of phenomena explained by internalization theory (Rugman, 1983). However, we have argued that SOEs represent a unique opportunity for extending internalization theory by taking into account issues that previously have received scant attention within the theory such as SOEs' non-economic objectives, time horizons, risk tolerance, and corporate governance features. Based on the fact that such features may vary across home contexts, we also take into account the home context of SOEs in terms of government quality and market orientation. Our empirical design with one host country, a relatively unbiased liberal market economy with low entry barriers attracting SOE and POE investments from widely varied home contexts (CERI, 2013), has allowed us to focus on the effects of state ownership and home-country characteristics. The oil and gas industry is also an appropriate setting to explore the role of non-economic motives, given its strategic importance for any country, as well as of risk tolerance, given the substantial investments involved.

Our study demonstrates that the applicability of internalization theory to SOEs has several facets. Although apparently not recognized in the literature so far, some aspects of SOEs seem to be fully reconcilable with traditional internalization theory, such as the effects of state ownership on FSAs, which in turn, might influence internalization decisions made by SOEs. Our theoretical contribution here consists of linking governance to FSAs, and in turn exploring how these systematic patterns of FSAs may affect internalization decisions. Other aspects, such as non-economic motivations for internalization and different risk tolerances, 
however, have required an extension of internalization theory. Importantly, our analysis also highlights the heterogeneity of SOEs, with SOEs from contexts with strong government quality and market orientation behaving very similarly to POEs suggesting that traditional internalization theory is applicable to such SOEs. A recent study of the internationalization performance of large listed MNEs in Norway - a country that scores highly on institutional factors - reports that SOEs perform on par with POEs, which suggests that economic efficiency is equally important and attainable for such SOEs (Benito, Rygh, \& Lunnan, 2016).

We expand the domain of the phenomena that internalizaton theory explains to include SOEs more generally. SOEs represent a potential "boundary condition" for internalization theory - but also a unique opportunity to extend the theory. However, we also argue that not all SOEs are the same. In particular, taking SOEs' governance contexts into account is important to understand their relationship to internalization theory, as key characteristics such as non-economic goals, risk preferences, and corporate governance issues are systematically influenced by SOEs' home-country contexts. Estrin et al. (2016) recently found that internationalization levels of SOEs with strong home-country corporate governance largely resemble the internationalization levels of POEs. We extend their findings to specific establishment and entry mode decisions. Our empirical study of entry modes of SOEs and POEs in the Canadian oil and gas industry between 2005 and 2016, confirms that both ownership - POE versus SOE - and homecountry context matter for companies' establishment and entry mode decisions. Specifically, we find that SOEs (particularly fully state-owned) from countries with less professional government institutions and weak market orientation show a propensity to take lower ownership positions, whereas POEs from such countries show a preference for high ownership stakes. In contrast, SOEs from home countries with well-functioning government institutions and market orientation make choices that are essentially indistinguishable from their POE counterparts. Partly owned SOEs, which seem to have become ever more common, exhibit ownership choices more similar to those of POEs.

For establishment mode decisions, our results indicate that fully owned SOEs prefer to enter by purchasing stand-alone assets instead of acquiring firms. They do so largely irrespective of their homecountry context, which points to a distinctive feature of fully owned SOEs. This is consistent with the assumption that SOEs with 100\% state ownership may pursue non-economic motives such as resource security (Bass \& Chakrabarty, 2014), and are thus not primarily seeking to reduce transaction costs. Conversely, our results show that POEs from countries characterized by lesser government institutions and weak market orientation are prone to enter by acquiring firms. However, the preference for acquisitive entries diminishes markedly for POEs that originate in home countries characterized by stronger home institutions. While these results are consistent with Madhok \& Keyhani's (2012) argument that firms from emerging markets prefer acquisitions to overcome liability of foreignness, we see a clear divergence in behavior among POEs and SOEs among firms from countries with inefficient government institutions and weak market orientation. For home-country contexts with stronger home institutions, POE and SOE again display very similar entry patterns. As such, it is the fully owned SOEs that represent a clear boundary condition for internalization theory inasmuch they are seemingly the least affected by their home context.

In sum, our findings suggest that it is not necessarily state ownership per se that challenges the underlying assumptions of internalization theory, but rather the combined effects of a chosen ownership structure and home-country institutional factors. Partially owned SOEs represent an interesting in-between category, showing similar trends to POEs, in line with Estrin et al.'s (2016) finding that hybrid SOEs emulate internationalization decisions of POEs when home-country institutions are stronger. Taken together, our findings demonstrate the need to adopt a more nuanced approach when discussing SOE characteristics (Musacchio \& Lazzarini, 2014).

\section{Contributions}

This study advances internalization theory by showing that SOEs represent a challenge to traditional internalization theory, but also by suggesting how this challenge can be used to extend and generalize the theory once adequate attention is given to non-economic benefits of internalization, risk preferences, and potential corporate governance challenges (which, in turn, affect FSA development). Insights on corporate governance have been found in related economic theories of corporate governance, such as agency theory. Although our core arguments are not restricted to SOEs, SOEs 
represent a very suitable laboratory for exploring the role of corporate governance features more generally for internalization decisions. Overall, our study supports Buckley and Strange's view of "the potential usefulness of agency theory as a complement to internalization theory in understanding the governance of the MNE" (2011: 468).

We identify that the applicability of traditional internalization theory is not contingent on state ownership per se, but depends on a combination of the level of state ownership and the home-country context, unlike Rugman's (1983) previous assumption, state ownership in itself does not exclude the applicability of traditional internalization theory. Indeed, SOEs and POEs from home-country contexts with high government quality and a strong market orientation behave similarly in terms of their establishment and entry mode choices, suggesting that internalization theory is applicable for both types of firms in such home-country contexts. We also identify an important distinction between the strategic decisions among SOEs with $100 \%$ state ownership and hybrid SOEs, where hybrid SOEs behave more similarly to POEs than fully SOEs do, even in weaker home-country contexts.

Our study also contributes original theoretical arguments and new empirical evidence to the growing literature on SOE internationalization, demonstrating that an enriched version of internalization theory is relevant for a phenomenon so far mainly studied from the perspective of institutional theory. Empirically, along with studies like Bass and Chakrabarty (2014), Estrin et al. (2016) and Karolyi and Liao (2017), our study also provides a much needed counterbalance to the dominance of the case of China in recent SOE internationalization literature in general (see Martin \& Li, 2015) and SOE entry strategy studies in particular. Our study furthermore contributes to the analysis of internationalization in the natural resources sector in general and the oil and gas industry in particular. Despite their economic significance for individual countries and the global economy, natural resources industries are surprisingly undervalued as contexts for theory development (George et al., 2015).

In addition, our study provides contributions to the entry mode literature (Welch, et al., 2018). Shaver (2013) and Hennart and Slangen (2015) recently debated whether more entry mode studies are needed. Our study indicates that one avenue of research that can help sustain the vitality of the entry mode literature is to consider alternative motives for internalization, time horizons, the role of risk preferences (Elia et al., 2019), and more general effects of corporate governance and ownership on FSA development and strategies. As such, our study also speaks to Shaver's (2013: 25) suggestion of studying the differences between what firms do and "what they should be doing". Indeed, the study also provides a broader view on the question of what firms "should be doing" by recognizing that there may be alternative and legitimate motives for internalization beyond purely economic ones.

Finally, our study also has policy implications that address the widespread policy concerns about the degree of foreign SOE control of firms and to what extent FDI contributes to new economic activity and long-term presence (Cuervo-Cazurra, 2018; Shapiro \& Globerman, 2012). The fact that the effect of state ownership seems to depend on the home-country context suggests that broadbrushed host-country policies targeting firms with particular types of ownership may not be appropriate. However, while our investigation of strategic entry decisions provides a basis for a better understanding of such choices, we do not look at their performance implications (cf. again Shaver, 2013); as discussed below, the latter should be investigated in future studies.

Our findings also have implications for homecountry policies. Home countries that treat SOEs relatively similar to POEs, enable their SOEs to compete at par when internationalizing. Our findings are thus well aligned with Benito et al. (2016) who find that Norwegian commercially oriented SOEs do not necessarily achieve lower results in international operations. Finally, the introduction of non-economic motives may also suggest new types of managerial implications that can be further explored. For instance, SOE managers pursuing welfare-maximizing home government policies may need to choose other internalization decisions than their POE peers. This might for instance imply a lesser emphasis on using internalization to appropriate economic value and protect FSAs.

\section{Limitations and Directions for Future Research}

While our study suggests that SOEs represent a useful laboratory for extending internalization theory, together with related studies such as Pan et al. (2014) this is just a first step. In this respect, while we have focused on state ownership and the alternative motives to profit maximization this might entail, our study also implies that further 
types of owners and their motivations could be interesting to study, including business group owners (Gaur, Pattnaik, Lee, \& Singh, 2019).

Our empirical context of Canada was highly suitable for this study, and the presence of SOEs from multiple home countries promotes generalizability, but future studies should investigate if the results hold for other host countries. This includes other countries with competitive markets such as Australia (Drysdale, 2011) as well as countries with less competitive markets such as, for instance, a number of African countries receiving substantial natural resource sector FDI (Asiedu, 2006). Although the oil and gas industry was highly suited for this study, studies of other industries are also needed to generalize the findings. Our focused study with SOEs from several home-country contexts has enabled us to outline arguments and hypotheses that can be tested on larger multicountry and multi-industry sample in future studies.

There are also rich opportunities for future research on the role of state ownership for other internalization decisions (Benito, Petersen, \& Welch, 2012; Welch et al., 2018), especially as events unfold over time (Contractor, Kumar, Kundu, \& Pedersen, 2010). Given our focus on decisions about how to enter foreign markets, we cannot capture potential differences in post-entry behavior of SOEs and POEs. In some contexts, state ownership may raise questions about the relevance of the assumed "selection mechanisms" leading to the survival of transaction cost minimizing organizational forms. Li and Xie (2013) argued that SOEs are not equally subject to market selection mechanisms that force firms to choose efficient operating modes. An SOE soft budget constraint (Kornai, 1979) could here play a role. Future studies could consider such differences, as well as differences in the performance following from the internalization decisions. An interesting avenue for research could also be to see to what extent SOEs modify their internalization decisions over time based on economic and non-economic objectives. Finally, the potential importance of micro-foundations - such as the role of biases - should also be studied more closely (Elia et al., 2019), also at the level of individual decision-makers. In the context of SOEs, an interesting avenue for research is to study the specific risk perceptions of individual SOE managers when going abroad.

\section{ACKNOWLEDGEMENTS}

We thank three anonymous reviewers and the Special Issue Editors Christian G. Asmussen, Tailan Chi, Sumit Kundu, and Rajneesh Narula for their guidance and many constructive comments, which were instrumental to the development of this paper. We are also grateful for the feedback received from participants at the Paper Development Workshop for this Special Issue held in Minneapolis in June 2018, particularly from our discussant Ajai Gaur. Thanks also to Alvaro Cuervo-Cazurra, Sjoerd Beugelsdijk, Alessandra Luzzi and José Pla-Barber for helpful comments on this research. Previous versions of this article were presented at the 2018 ElBA Annual Conference (Poznan), 2015 AIB Annual Conference (Bangalore), 2015 Reading-UNCTAD Conference (Reading), 2014 EIBA Annual Conference (Uppsala), and in seminars at Alliance Manchester Business School (University of Manchester), BI Norwegian Business School, Haskayne Business School (University of Calgary), Henley Business School (University of Reading), and Turku School of Economics (University of Turku). We are grateful for the many comments and suggestions provided by colleagues attending the presentations. The usual disclaimer applies. We are grateful for the financial support from BI Norwegian Business School, Haskayne School of Business (University of Calgary), and the MAROFF project (Norwegian Research Council). We have also benefited from the support of the Centre for Corporate Governance Research at BI Norwegian Business School.

\section{OPEN ACCESS}

This article is licensed under a Creative Commons Attribution 4.0 International License, which permits use, sharing, adaptation, distribution and reproduction in any medium or format, as long as you give appropriate credit to the original author(s) and the source, provide a link to the Creative Commons licence, and indicate if changes were made. The images or other third party material in this article are included in the article's Creative Commons licence, unless indicated otherwise in a credit line to the material. If material is not included in the article's Creative Commons licence and your intended use is not permitted by statutory regulation or exceeds the permitted use, you will need to obtain permission directly from the copyright holder. To view a copy of this licence, visit http:// creativecommons.org/licenses/by/4.0/. 


\section{NOTES}

${ }^{1}$ In this paper, we refer to all public (i.e., listed) and private (i.e., non-listed) companies without any state ownership as privately owned enterprises (POEs) since we are interested in examining effects of state ownership rather than differences between private and public ownership.

${ }^{2}$ Rugman referred to SOEs as 'political animals' in an era where SOEs typically experienced more political influence. However, he did recognize that the applicability of the theory was contingent on potential political and social goals of the state owner.

${ }^{3}$ Our focus here is on long-term capital investments, not the actual deal value. Exploratory standalone assets are highly uncertain in terms of the capital required for exploration and development activities. Economic benefits are only obtained after the asset is producing oil or gas.

${ }^{4}$ The database includes all publicly announced transactions between 2008 and 2016. Some smaller M\&As are missing between 2005 and 2007 and data on government lease sales has been supplemented for all years. We exclude transactions involving an ownership share of less than the common cut-off FDI value of $10 \%$.

${ }^{5}$ In general, a marginal effect indicates the effect on the conditional mean of the dependent variable of a change in an independent variable. In the plots the marginal effect of state ownership is considered at different levels of the home-country institutional variables. We use the marginal effects version which when fixing certain variables of interest is holding the other independent variables at their observed values, rather than at the mean. This computes a predicted probability for each case with the fixed and observed values of variables, before averaging the predicted values. Many scholars prefer average marginal effects (AME) over the marginal effect at the means (MEM) as the former makes use of more data and is seen as more intuitive than using means which may not correspond to any observation in the dataset (Williams, 2012).

${ }^{6}$ In the case of comparing independent means as well as comparing correlations, Cumming (2009) notes an overlap of maximum half the average margin of error (i.e., the average of the length of one "arm" of the confidence interval for the two samples) corresponds to significance at about 5\%. Non-overlapping confidence intervals correspond to significance at $1 \%$ or lower.

${ }^{7}$ An unfortunate characteristic of the confidence intervals of the predictions for the logit models is that some of them go outside the admissible $0-1$ range for probabilities. However, we choose to retain the original intervals produced by Stata rather than, for instance, censoring them as sometimes suggested.

${ }^{8}$ We would like to thank an anonymous reviewer for this excellent suggestion.

Benito, G. R. G., Petersen, B., \& Welch, L. S. 2012. Dynamics of foreign operation modes and their combinations: Insights for international strategic management". In A. Verbeke \& H. Merchant (Eds), Handbook of research on international strategic management: 93-115. Cheltenham: Edward Elgar.

Benito, G. R. G., Rygh, A., \& Lunnan, R. 2016. The benefits of internationalization for state-owned enterprises. Global Strategy Journal, 6(4): 269-288.

Berry, W. D., Golder, M., \& Milton, D. 2012. Improving tests of theories positing interaction. Journal of Politics, 74(3): 653-671.

Bhaumik, S. K., Driffield, N., \& Pal, S. 2010. Does ownership structure of emerging-market firms affect their outward FDI? The case of the Indian automotive and pharmaceutical sectors. Journal of International Business Studies, 41(3): 437-450.

Bolton, P., \& Dewatripont, M. 2005. Contract theory. Cambridge, MA: The MIT Press.

Boycko, M., Shleifer, A., \& Vishny, R. 1996. A theory of privatisation. Economic Journal, 106(435): 309-319.

Brouthers, K. D., \& Hennart, J. F. 2007. Boundaries of the firm: Insights from international entry mode research. Journal of Management, 33(3): 395-425. 
Buckley, P. J. 1988. The limits of explanation: Testing the internalization theory of the multinational enterprise. Journal of International Business Studies, 19(2): 181-193.

Buckley, P. J., \& Casson, M. 1976. The future of the multinational enterprise. London: MacMillan.

Buckley, P., Doh, J., \& Benischke, M. 2017. Towards a renaissance in international business research? Big questions, grand challenges, and the future of IB scholarship. Journal of International Business Studies, 48(9): 1045-1064.

Buckley, P. J., \& Strange, R. 2011. The governance of the multinational enterprise: Insights from internalization theory. Journal of Management Studies, 48(2): 460-470.

Cannizzaro, A. P., \& Weiner, R. J. 2018. State ownership and transparency in foreign direct investment. Journal of International Business Studies, 49(2): 172-195.

CAPP. 2014. Canadian association of petroleum producers website. www.capp.ca/canadaindustry/naturalGas/ Conventional-Unconventional. Accessed 13 July 2015.

Cavaliere, A., \& Scabrosetti, S. 2008. Privatization and efficiency: From principals and agents to political economy. Journal of Economic Surveys, 22(4): 685-710.

CERI. 2013. Recent foreign investment in the Canadian oil and gas industry. Calgary: Canadian Energy Research Institute.

Chi, T., \& Roehl, T. W. 1997. The structuring of interfirm exchanges in business know-how: Evidence from international collaborative ventures. Managerial and Decision Economics, 18(4): 279-294.

Chiles, T. H., \& McMackin, J. F. 1996. Integrating variable risk preferences, trust, and transaction cost economics. Academy of Management Review, 21(1): 73-99.

Clegg, J., Voss, H., \& Tardios, J. A. 2018. The autocratic advantage: Internationalization of state-owned multinationals. Journal of World Business, 53(5): 668-681.

Contractor, F., Kumar, V., Kundu, S., \& Pedersen, T. 2010. Reconceptualizing the firm in a world of outsourcing and offshoring: The organizational and geographical relocation of high-value company functions. Journal of Management Studies, 47(8): 1417-1433.

Cuervo, A., \& Villalonga, B. 2000. Explaining the variance in the performance effects of privatization. Academy of Management Review, 25(3): 581-590.

Cuervo-Cazurra, A. 2018. Thanks but no thanks: State-owned multinationals from emerging markets and host-country policies. Journal of International Business Policy, 1(3-4): 128-156.

Cuervo-Cazurra, A., Inkpen, A., Musacchio, A., \& Ramaswamy, K. 2014. Governments as owners: State-owned multinational companies. Journal of International Business Studies, 45(8): 919-942.

Cui, L., \& Jiang, F. 2012. State ownership effect on firms' FDI ownership decisions under institutional pressure: A study of Chinese outward-investing firms. Journal of International Business Studies, 43(3): 264-284.

Cumming, G. 2009. Inference by eye: Reading the overlap of independent confidence intervals. Statistics in Medicine, 28(2): 205-220.

Datta, D. K., Hermann, P., \& Rasheed, A. A. 2002. Choice of foreign market entry modes: Critical review and future directions. Advances in Comparative International Management, $14,85-153$.

Drysdale, P. 2011. A new look at Chinese FDI in Australia. China \& World Economy, 19(4): 54-73.

Duanmu, J. L. 2014. State-owned MNCs and host country expropriation risk: The role of home state soft power and economic gunboat diplomacy. Journal of International Business Studies, 45(8): 1044-1060.

Eisenhardt, K. M. 1989. Agency theory: An assessment and review. Academy of Management Review, 14(1): 57-74.

Elia, S., Larsen, M. M., \& Piscitello, L. 2019. Entry mode deviation: A behavioral approach to internalization theory. Journal of International Business Studies, this issue.
Estrin, S., Meyer, K. E., Nielsen, B. B., \& Nielsen, S. 2016. Home country institutions and the internationalization of stateowned enterprises: A cross-country analysis. Journal of World Business, 51(2): 294-307.

Evans, P., \& Rauch, J. E. 1999. Bureaucracy and growth: A crossnational analysis of the effects of "Weberian" state structures on economic growth. American Sociological Review, 64(5): 748-765.

Fama, E. F., \& Jensen, M. C. 1983. Separation of ownership and control. Journal of Law and Economics, 26(2): 301-325.

Filatotchev, I., Strange, R., Piesse, J., \& Lien, Y.-C. 2007. FDI by firms from newly industrialised economies in emerging markets: Corporate governance, entry mode and location. Journal of International Business Studies, 38(4): 556-572.

Filatotchev, I., \& Wright, M. 2011. Agency perspectives on corporate governance of multinational enterprises. Journal of Management Studies, 48(2): 471-486.

Fortune. 2007. Fortune 500 Global. http://archive.fortune.com/ magazines/fortune/fortune_archive/2007/07/23/100135836/ index.htm?postversion $=2007071113$. Accessed 15 November 2017.

Fortune. 2017. Fortune 500 Global. http://fortune.com/ global500/. Accessed 15 November 2017.

Garcia, R., Lessard, D., \& Singh, A. 2014. Strategic partnering in oil and gas: A capabilities perspective. Energy Strategy Reviews, 3, 21-29.

Gaur, A. S., Ma, X., \& Ding, Z. 2018. Home country supportiveness/unfavorableness and outward foreign direct investment from China. Journal of International Business Studies, 49(3): 324-345.

Gaur, A., Pattnaik, C., Lee, J. Y., \& Singh, D. 2019. Internalization advantage and subsidiary performance: The role of business group affiliation and host country characteristics. Journal of International Business Studies, this issue.

George, G., Schillebeeckx, S. J., \& Liak, T. L. 2015. The management of natural resources: An overview and research agenda. Academy of Management Journal, 58(6): 1595-1613.

Goldeng, E., Grünfeld, L. A., \& Benito, G. R. G. 2008. The performance differential between private and state-owned enterprises: The roles of ownership, management and market structure. Journal of Management Studies, 45(7): 1244-1273.

Grøgaard, B., \& Verbeke, A. 2012. Twenty key hypotheses that make internalization theory the general theory of international strategic management. In A. Verbeke \& H. Merchant (Eds), Handbook of research on international strategic management: 7-30. Cheltenham: Edward Elgar.

Gugler, P. 2017. Emerging countries' country-specific advantages (CSAs) and competitiveness of emerging market multinational enterprises (EMNEs). Competitiveness Review, 27(3): 194-207.

Hart, O., Shleifer, A., \& Vishny, R. W. 1997. The proper scope of government: Theory and an application to prisons. Quarterly Journal of Economics, 112(4): 1127-1161.

Hennart, J.-F. 1982. A theory of multinational enterprise. Ann Arbor: University of Michigan Press.

Hennart, I.-F. 2009. Down with MNE-centric theories! Market entry and expansion as the bundling of MNE and local assets. Journal of International Business Studies, 40(9): 1432-1454.

Hennart, J.-F. 2012. Emerging market multinationals and the theory of the multinational enterprise. Global Strategy Journal, 2(3): 168-187.

Hennart, J.-F., \& Slangen, A. H. 2015. Yes, we really do need more entry mode studies! A commentary on Shaver. Journal of International Business Studies, 46(1): 114-122.

Hoenen, A. K., \& Kostova, T. 2015. Utilizing the broader agency perspective for studying headquarters-subsidiary relations in multinational companies. Journal of International Business Studies, 46(1): 104-113.

Hu, H. W., Cui, L., \& Aulakh, P. S. 2019. State capitalism and performance persistence of business group-affiliated firms: A 
comparative study of China and India. Journal of International Business Studies, 50(2): 193-222.

Jensen, M. C., \& Meckling, W. H. 1976. Theory of the firm: Managerial behavior, agency costs and ownership structure. Journal of Financial Economics, 3(4): 305-360.

Johanson, J., \& Vahlne, J.-E. 2009. The Uppsala internationalization process model revisited: From liability of foreignness to liability of outsidership. Journal of International Business Studies, 40(9): 1411-1431.

JuneWarren Nickle's Energy Group. 2016. Operational and financial data on oil and gas companies 01/01/2005 to 03/31/2016 [Data file]. http://www.junewarren-nickles.com/. Accessed 31 July 2018.

Kano, L. 2018. Global value chain governance: A relational perspective. Journal of International Business Studies, 49(6): 684-705.

Karolyi, G. A., \& Liao, R. C. 2017. State capitalism's global reach: Evidence from foreign acquisitions by state-owned companies. Journal of Corporate Finance, 42, 367-391.

Kingsley, A. F., Noordewier, T. G., \& Bergh, R. G. V. 2017. Overstating and understating interaction results in international business research. Journal of World Business, 52(2): 286-295.

Knutsen, C. H., Rygh, A., \& Hveem, H. 2011. Does state ownership matter? Institutions' effect on foreign direct investment revisited. Business and Politics, 13(1): art. 2.

Kornai, J. 1979. Resource-constrained versus demand-constrained systems. Econometrica, 47(4): 801-820.

Laffont, J. J., \& Martimort, D. 2002. The theory of incentives: The principal-agent model. Princeton: Princeton University Press.

Lawson, C. 1994. The theory of state-owned enterprises in market economies. Journal of Economic Surveys, 8(3): 283-309.

Lee, Y., Hemmert, M., \& Kim, J. 2014. What drives the international ownership strategies of Chinese firms? The role of distance and home-country institutional factors in outward acquisitions. Asian Business \& Management, 13(3): 197-225.

Li, J., \& Xie, Z. 2013. Examining the cross-border acquisition strategy of Chinese companies: The moderating roles of state ownership and institutional transition. Journal of Leadership \& Organizational Studies, 20(4): 436-447.

Madhok, A., \& Keyhani, M. 2012. Acquisitions as entrepreneurship: Asymmetries, opportunities, and the internationalization of multinationals from emerging economies. Global Strategy Journal, 2(1): 26-40.

Martimort, D. 2006. An agency perspective on the costs and benefits of privatization. Journal of Regulatory Economics, 30(1): 5-44.

Martin, X., \& Li, C. 2015. What do we know about state-owned emerging-economy firms, and how? Evaluating literature about inward and outward multinational activities. Advances in International Management, 28, 403-439.

Megginson, W. L., \& Netter, J. M. 2001. From state to market: A survey of empirical studies on privatization. Journal of Economic Literature, 39(2): 321-389.

Meyer, K. E., Ding, Y., Li, J., \& Zhang, H. 2014. Overcoming distrust: How state-owned enterprises adapt their foreign entries to institutional pressures abroad. Journal of International Business Studies, 45(8): 1005-1028.

Miller, T., \& Kim, A. B. 2017. 2017 Index of Economic Freedom. Washington DC: The Heritage Foundation.

Morschett, D., Schramm-Klein, H., \& Swoboda, B. 2010. Decades of research on market entry modes: What do we really know about external antecedents of entry mode choice? Journal of International Management, 16(1): 60-77.

Muehlfeld, K., Rao Sahib, P., \& Van Witteloostuijn, A. 2012. A contextual theory of organizational learning from failures and successes: A study of acquisition completion in the global newspaper industry, 1981-2008. Strategic Management Journal, 33(8): 938-964.

Musacchio, A., \& Lazzarini, S. G. 2014. Reinventing state capitalism: Leviathan in business, Brazil and beyond. Cambridge, MA: Harvard University Press.
Musacchio, A., Lazzarini, S., \& Aguilera, R. 2015. New varieties of state capitalism: Strategic and governance implications. Academy of Management Perspectives, 29(1): 115-131.

Narula, R., \& Verbeke, A. 2015. Making internalization theory good for practice: The essence of Alan Rugman's contributions to international business. Journal of World Business, 50(4): 612-622.

Newfoundland Department of Natural Resources. 2016. Publications energy. http://www.nr.gov.nl.ca/nr/publications/ energy/index.html. Accessed 2 December 2017.

OECD. 2013. International investments by SOEs: Economic trends and the policy landscape. Paris: OECD Publishing.

OECD. 2014. Levelling the international playing field between public and private business: What have we learnt so far?. Paris: OECD Publishing.

Okhuysen, G., \& Bonardi, J.-P. 2011. The challenges of building theory by combining lenses. Academy of Management Review, 36(1): 6-11.

Pan, Y., Teng, L., Supapol, A. B., Lu, X., Huang, D., \& Wang, Z. 2014. Firms' FDI ownership: The influence of government ownership and legislative connections. Journal of International Business Studies, 45(8): 919-942.

Rugman, A. M. 1981. Inside the multinationals: The economics of the multinational enterprise. New York: Columbia University Press.

Rugman, A. M. 1983. The comparative performance of US and European multinational enterprises, 1970-79. Management International Review, 23(2): 4-14.

Rugman, A. M., \& Li, J. 2007. Will China's multinationals succeed globally or regionally? European Management Journal, 25(5): 333-343.

Rugman, A. M., \& Verbeke, A. 2001. Subsidiary-specific advantages in multinational enterprises. Strategic Management Journal, 22(3): 237-250.

Rugman, A. M., \& Verbeke, A. 2003. Extending the theory of the multinational enterprise: Internalization and strategic management perspectives. Journal of International Business Studies, 34(2): 125-137.

Rugman, A. M., \& Verbeke, A. 2008. Internalization theory and its impact on the field of international business. Research in Global Strategic Management, 14, 155-174.

Rygh, A. 2018. Welfare effects of state-owned multinational enterprises: A view from agency and incomplete contracts theory. International Journal of Public Sector Management, 31(2): 207-220.

Sappington, D. E., \& Stiglitz, J. E. 1987. Privatization, information and incentives. Journal of Policy Analysis and Management, 6(4): 567-585.

Shapiro, D. \& Globerman, S. 2012. The international activities and effects of state-owned enterprises. In K. Sauvant, L. Sachs, \& W. S. Jongbloed (Eds), Sovereign investment: Concerns and policy reactions: 98-141. New York: Oxford University Press.

Shaver, J. M. 2013. Do we really need more entry mode studies? Journal of International Business Studies, 44(1): 23-27.

Shi, W., Sun, S., Yan, D., \& Zhu, Z. 2017. Institutional fragility and outward foreign direct investment from China. Journal of International Business Studies, 48(4): 452-476.

Shleifer, A., \& Vishny, R. W. 1994. Politicians and firms. Quarterly Journal of Economics, 109(4): 995-1025.

Shleifer, A., \& Vishny, R. W. 1997. A survey of corporate governance. Journal of Finance, 52(2): 737-783.

Slangen, A., \& Hennart, J.-F. 2007. Greenfield or acquisition entry: A review of the empirical foreign establishment mode literature. Journal of International Management, 13(4): 403-429.

Stock, J. H., Wright, J. H., \& Yogo, M. 2002. A survey of weak instruments and weak identification in generalized method of moments. Journal of Business and Economic Statistics, 20(4): 518-529. 
Strange, R. 2018. Corporate ownership and the theory of the multinational enterprise. International Business Review, 27(6): 1229-1237.

Strange, R., Filatotchev, I., Buck, T., \& Wright, M. 2009. Corporate governance and international business. Management International Review, 49(4): 395-407.

Teorell, J., Dahlberg, S., Holmberg, S., Rothstein, B., Pachon, N. A., \& Svensson, R. 2018. The Quality of Government standard dataset, version jan18 [Online]. Gothenburg: Quality of Government Institute. http://www.qog.pol.gu.se. Accessed 1 February 2018.

Tihanyi, L., Griffith, D. A., \& Russell, C. J. 2005. The effect of cultural distance on entry mode choice, international diversification, and MNE performance: A meta-analysis. Journal of International Business Studies, 36(3): 270-283.

UNCTAD. 2017. Investment and the Digital Economy, World Investment Report. Geneva: UNCTAD.

Vernon, R. 1979. The international aspects of state-owned enterprises. Journal of International Business Studies, 10(3): 7-15.

Welch, L. S., Benito, G. R. G., \& Petersen, B. 2018. Foreign operation methods: Theory, analysis, strategy (2nd ed.). Cheltenham, UK: Edward Elgar.

Williams, R. 2012. Using the margins command to estimate and interpret adjusted predictions and marginal effects. The Stata Journal, 12(2): 308-331.

Zelner, B. A. 2009. Using simulation to interpret results from logit, probit, and other nonlinear models. Strategic Management journal, 30(12): 1335-1348.

\section{ABOUT THE AUTHORS}

Birgitte Grogaard is an Associate Professor in the Department of Strategy and Entrepreneurship at BI Norwegian Business School in Oslo, Norway. Her research interests include strategies of multinational enterprises, headquarter-subsidiary relationships, and foreign direct investments. Her work has been published in various international business journals including the Journal of International Business Studies, Journal of World Business, and Management International Review. She has also coauthored the book Global Strategy and Management (with P. Gooderham and K. Foss, 2019). Prior to pursuing her Ph.D., Birgitte worked in a multinational oil and gas company.

Asmund Rygh is a Lecturer in International Business at Alliance Manchester Business School, University of Manchester (UK). He has a Ph.D. in Business and Economics from BI Norwegian Business School (Oslo, Norway), and an MA in Economics from the University of Oslo (Oslo, Norway). His main research interests include corporate governance and finance, state ownership, and corporate social responsibility. Previous publications include articles in Global Strategy Journal, Management International Review, Business and Politics and International Journal of Public Sector Management, as well as several book chapters.

Gabriel R. G. Benito is Professor at Department of Strategy and Entrepreneurship, BI Norwegian Business School, Oslo. He is a Fellow of Academy of International Business and a Fellow of European International Business Academy. His current research agenda focuses on corporate governance, and strategies and organization of multinational enterprises. His work includes the books Foreign Operation Methods (with L.S. Welch and B. Petersen, 2nd edition, 2018) and Multinationals on the Periphery (with R. Narula, 2007) and numerous articles in Journal of International Business Studies, Journal of Management Studies, and Journal of Economic Geography, among others.

Publisher's Note Springer Nature remains neutral with regard to jurisdictional claims in published maps and institutional affiliations.

Accepted by Christian Geisler Asmussen, Tailan Chi, and Rajneesh Narula, Special Issue Guest Editors, 17 January 2019. This article has been with the authors for three revisions. 